\title{
3. SEISMIC STRATIGRAPHY OF THE ONTONG JAVA PLATEAU ${ }^{1}$
}

\author{
David C. Mosher, ${ }^{2}$ Larry A. Mayer, ${ }^{2,3}$ Tom H. Shipley, ${ }^{4}$ Edward L. Winterer ${ }^{5}$ Rick A. Hagen, ${ }^{6}$ Janice C. Marsters, ${ }^{6}$ \\ Franck Bassinot, ${ }^{7}$ Roy H. Wilkens, ${ }^{6}$ and Mitchell Lyle ${ }^{8}$
}

\begin{abstract}
The Ontong Java Plateau, a large, deep-water carbonate plateau in the western equatorial Pacific, is an ideal location for studying responses of carbonate sedimentation to the effects of changing paleoceanographic conditions. These carbonate responses are often reflected in the physical properties of the sediment, which in turn control the appearance of seismic reflection profiles. Seismic stratigraphy analyses, correlating eight reflector horizons to each drill site, have been conducted in an attempt to map stratigraphic data. Accurate correlation of seismic stratigraphic data to drilling results requires conversion of traveltime to depth in meters. Synthetic seismogram models, using shipboard physical properties data, have been generated in an attempt to provide this correlation.

Physical properties, including laboratory-measured and well-log data, were collected from sites drilled during Deep Sea Drilling Project Legs 30 and 89, and Ocean Drilling Program Leg 130, on the top and flank of the Ontong Java Plateau. Laboratory-measured density is corrected to in-situ conditions by accounting for porosity rebound resulting from removal of the sediment from its overburden. The correction of laboratory-measured compressional velocity to in situ appears to be largely a function of increases in elastic moduli (especially shear rigidity) with depth of burial, more than a function of changes in temperature, pressure, or density (porosity rebound). Well-log velocity and density data for the ooze intervals were found to be greatly affected by drilling disturbance; hence, they were disregarded and replaced by lab data for these intervals.

Velocity and density data were used to produce synthetic seismograms. Correlation of seismic reflection data with synthetic data, and hence with depth below seafloor, at each drill site shows that a single velocity-depth function exists for sediments on the top and flank of the Ontong Java Plateau. A polynomial fit of this function provides an equation for domain conversion:

Depth $(\mathrm{mbsf})=44.49+0.800($ traveltime $[\mathrm{ms}])+3.308 \times 10^{-4}\left(\right.$ traveltime $\left.[\mathrm{ms}]^{2}\right)$

Traveltime $(\mathrm{ms})=-35.18+1.118($ depth $[\mathrm{mbsf}])-1.969 \times 10^{-4}\left(\mathrm{depth}[\mathrm{mbsf}]^{2}\right)$

Seismic reflection profiles down the flank of the plateau undergo three significant changes: (1) a drastic thinning of the sediment column with depth, (2) changes in the echo-character of the profile (development of seismic facies), and (3) loss of continuous, coherent reflections. Sediments on the plateau top were largely deposited by pelagic processes, with little significant postdepositional or syndepositional modification. Sediments on the flank of the plateau are also pelagic, but they have been modified by faulting, erosion, and mass movement. These processes result in disrupted and incoherent reflectors, development of seismic facies, and redistribution of sediment on the flank of the plateau.

Seismic stratigraphic analyses have shown that the sediment section decreases in thickness by as much as $65 \%$ between water depths of $2000 \mathrm{~m}$ water depth (at the top of the plateau) and $4000 \mathrm{~m}$ (near the base of the plateau). Thinning is attributed to increasing carbonate dissolution with depth. If this assumption is correct, then changes in the relative thicknesses of seismostratigraphic units at each drill site are indicative of changes in the position of the lysocline and the dissolution gradient between the lysocline and the carbonate compensation depth. We think that a shallow lysocline in the early Miocene caused sediment thinning. A deepening of the lysocline in the late-early Miocene caused relative thickening at each site. Within the middle Miocene, a sharp rise in lysoclinal depth occurs, concurrent with a steepening of the dissolution gradient. These events result in sediment thinning at all four sites. The thicker sections in the late Miocene likely correspond to a deepening of the lysocline, and a subsequent rise in the lysocline again hinders accumulation of sediment in the very late Miocene and Pliocene.
\end{abstract}

\section{INTRODUCTION}

Pelagic carbonate sediments are excellent indicators of past oceanographic conditions and processes. Responses to varying ocean-

\footnotetext{
${ }^{1}$ Berger, W.H., Kroenke, L.W., Mayer, L.A., et al., 1993. Proc. ODP, Sci. Results, 130: College Station, TX (Ocean Drilling Program).

${ }^{2}$ Department of Oceanography, Dalhousie University, Halifax, Nova Scotia B3H 4J1, Canada.

${ }^{3}$ Ocean Mapping Group, Department of Surveying Engineering, University of New Brunswick, P.O. Box 4400, Fredericton, New Brunswick E3B 5A3, Canada.

${ }^{4}$ Institute for Geophysics, University of Texas at Austin, 8701 Mopac Boulevard, Austin, TX 79759, U.S.A.

${ }^{5}$ Geological Research Division, Scripps Institution of Oceanography, University of California, San Diego, La Jolla, CA 92093, U.S.A.

${ }^{6}$ Department of Geology and Geophysics, School of Ocean and Earth Science and Technology, University of Hawaii, 2525 Correa Road, Honolulu, HI 96822, U.S.A.

${ }^{7}$ Laboratoire de Géologie du Quaternaire, Case 907, CNRS-Luminy, 13288 Marseille Cedex 9. France.

${ }^{8}$ Borehole Research Group, Lamont-Doherty Geological Observatory, Palisades, NY 10963, U.S.A.
}

ographic conditions can result in changes in sedimentation regimes and in physical properties of the sediment. Seismic reflection techniques can be used to investigate these changes remotely because sedimentation styles are often expressed in seismic reflection patterns, and because the acoustic response of a sedimentary sequence to an impulse is a function of physical properties changes within that sequence. This paper attempts to accurately correlate seismic reflection data to core data based on physical properties information from sediments of the Ontong Java Plateau collected during Ocean Drilling Program (ODP) Leg 130. These correlations will allow interpretation of the seismic reflection data with respect to stratigraphy, sedimentology, and paleoceanography of the Ontong Java Plateau, based on the geology in Leg 130 cores.

\section{Location and Geologic Setting}

The Ontong Java Plateau, at 1.5 million $\mathrm{km}^{2}$ in area, is the largest of the world's classic "oceanic" plateaus. It is located in the western equatorial Pacific north of the Solomon Islands (Fig. 1). At the top of 


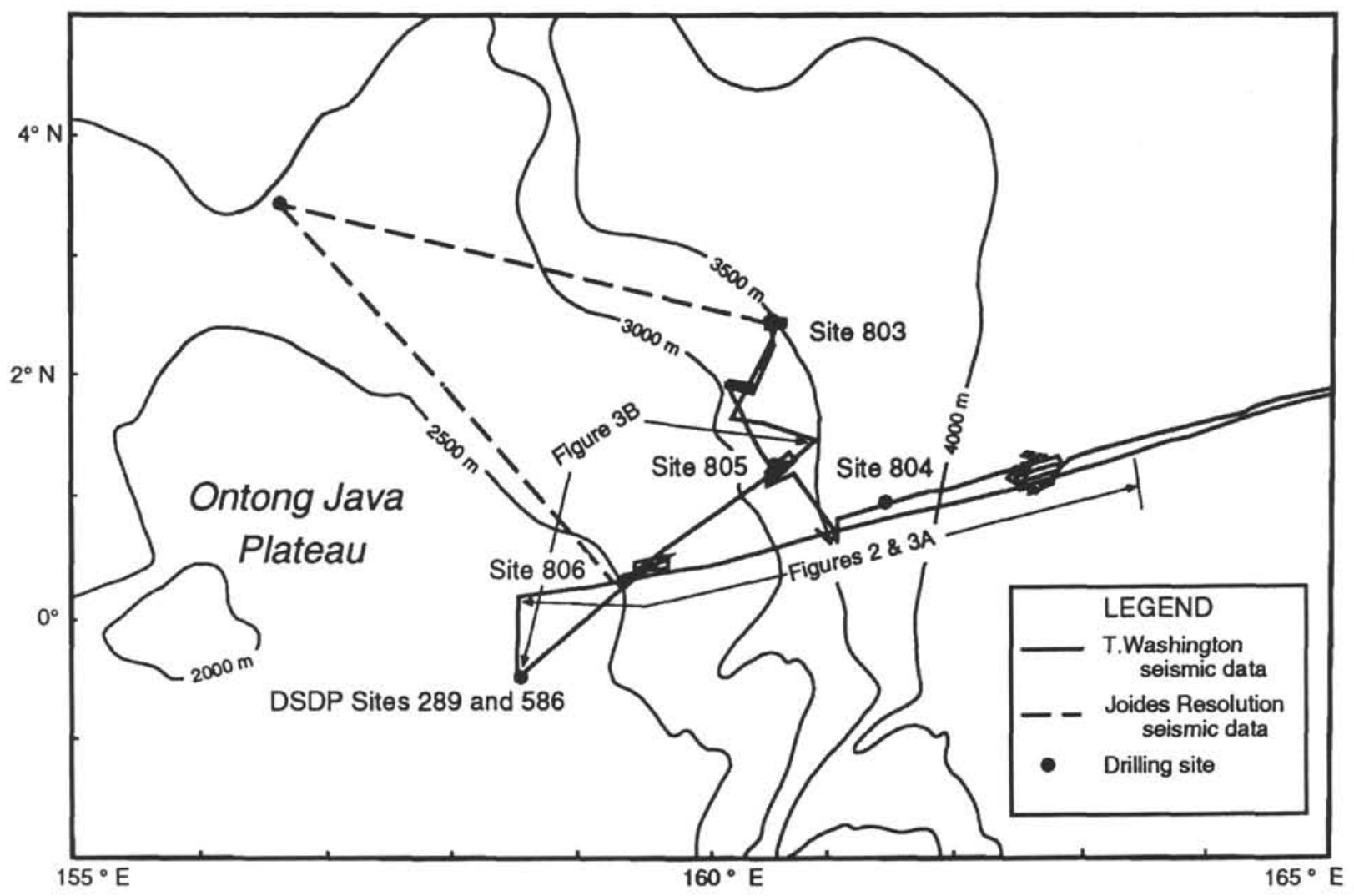

Figure 1. Location and bathymetric map of the Ontong Java Plateau, illustrating available seismic reflection data and the ODP Leg 130 and DSDP drilling site locations.

the plateau, approximately $1.5 \mathrm{~km}$ of well-stratified Mesozoic and Cenozoic pelagic sediments overlie basaltic crust (Shipboard Scientific Party, 1971, 1975; Kroenke, 1972; Shipboard Scientific Parties of Legs 89 and 90, 1986; Kroenke, Berger, Janecek, et al., 1991). In the Nauru Basin, immediately east of the plateau, sediment is $<300$ $\mathrm{m}$ thick. The slope of the flank of the plateau averages about $0.19^{\circ}$. Seismic refraction studies show the crust of the plateau to be approximately 40,000 m thick (Kroenke, 1972; Furumoto et al., 1976; Carlson et al., 1980). Crustal seismic velocities are on the order of those of oceanic crust, but the thicknesses of crustal layers on the Ontong Java Plateau are five times normal (Furumoto et al., 1976; Hussong et al., 1979; Carlson et al., 1980).

Several aspects of the Ontong Java Plateau's history make the plateau ideally suited for detailed paleoceanographic studies. First and foremost is the combination of its bathymetry and geographic location. The plateau, straddling the equator for much of its history, is located in a region characterized by relatively high production of biogenic sediment. The juxtaposition of the top of the plateau, at about $2000 \mathrm{~m}$, and the flank of the plateau, down to $4500 \mathrm{~m}$, requires that pelagic sediment in both locations will have been produced in similar surface-water conditions. Based on studies of benthic foraminifers, the plateau seems to have remained at a relatively constant water depth, at least since the Tertiary (Resig et al., 1976; Shipboard Scientific Party, 1975). Most of the plateau has, therefore, remained above the carbonate compensation depth (CCD) for at least the last 30 m.y. and has accumulated a thick pile of biogenous carbonate sediment that has not been subjected to pervasive dissolution. Sediments along a depth transect on the flank of the plateau have been exposed to increasingly deeper and more carbonate-corrosive waters. The depth range of the flank $(2000-4500 \mathrm{~m})$ is precisely that through which changes in dissolution gradients are most pronounced (Berger and Johnson, 1976; Berger and Mayer, 1978). The combination and constancy of bathymetry and geography of the Ontong Java Plateau, therefore, eliminate many of the variables normally associated with pelagic sedimentation (i.e., productivity and latitudinal gradients, and tectonic bathymetric changes) and create a nearly ideal natural laboratory for evaluating the vertical distribution of a range of oceanic parameters, both spatially and temporally.

\section{Background}

The main factors controlling pelagic carbonate sediment deposition and accumulation are (1) the productivity of foraminifers and coccoliths in the overlying surface water; (2) the dissolution of carbonate material as it falls through the water and lays on the seafloor; (3) the dilution of carbonate particles by noncarbonates, such as terrigenous particles, pelagic clay, volcanic detritus, or silica; and (4) the winnowing, scouring, and eroding of material on the bottom (Hamilton et al., 1982), as well as other sedimentation processes (Berger and Johnson, 1976; Berger et al., 1977). Mayer et al. $(1985,1986)$ have shown that the major sedimentary response to paleoceanographic events in the central equatorial Pacific is fluctuations in the amount of calcium carbonate dissolution. They have shown that there are basin-wide, seismically expressed sedimentary responses for paleoceanographic events related to increased dissolution. Although discrete periods of increased carbonate dissolution create events that are extremely useful from a seismic or stratigraphic perspective, complete removal or severe compression of the section that results from this dissolution makes detailed evaluation of such paleoceanographic indicators as isotopic signals, faunal changes, and chemical tracers virtually impossible at these critical times. The Ontong Java Plateau provides a setting in which Neogene and Quaternary sediment at the top of the plateau, in $2000 \mathrm{~m}$ of water, has undergone little carbonate dissolution, and thus the section is relatively expanded. The flank of the plateau extends through the present and past lysoclines and CCDs (van Andel et al., 1975; Berger et al., 1977). 
A seismic reflection profile, transecting the flank of the plateau, can potentially yield a continuous record, in both spatial and temporal senses, of the sedimentary column. Tied to drill sites to provide valuable stratigraphic data, seismic reflection profiling becomes a powerful tool for interpretation and extrapolation of the sedimentary history of this region.

\section{METHODS}

\section{Seismic Reflection}

Three thousand kilometers of digital, single-channel seismic reflection data have been acquired from the study area on the Ontong Java Plateau during Roundabout Leg 11 of the Thomas Washington in December 1988 (Fig. 1) (Mayer et al., 1991). The seismic data were collected using a $1.3 \mathrm{~L}\left(80 \mathrm{in}^{3}\right)$ ), 136 atm (2000 psi) SSI water-gun source. The water-gun source has a much broader bandwidth than conventional air guns and, because it does not expel air, does not produce bubble reverberations. A Teledyne streamer with 48 acceleration-canceling hydrophones in a linear array was used to receive the acoustic signals. Depth was monitored with a calibrated depth sensor at the head of the leader. Towing depth was held around $5 \mathrm{~m}$ for both the gun and the streamer. Data were digitally recorded at sampling intervals of $1 \mathrm{~ms}$ on nine-track magnetic tape with amplitude preservation for later processing and display.

Single-channel seismic reflection data were also collected from the JOIDES Resolution during Leg 130 (Fig. 1). The source system consisted of two synchronized $1.3 \mathrm{~L}$ (80 in. ${ }^{3)}, 136 \mathrm{~atm}$ (2000 psi) SSI water guns. The receiver consisted of a $100-\mathrm{m}$ long Teledyne Model 178 streamer, towed at a depth of about $10 \mathrm{~m}$. These data were also logged at 1-ms sampling rates on magnetic tape (Kroenke, Berger, Janecek, et al., 1991).

The Thomas Washington seismic reflection data consist of two lines that run up the flank of the Ontong Java Plateau, tying into Deep Sea Drilling Project (DSDP) Sites 289 and 586, plus six areas on the flank that were surveyed in some detail as proposed (and later drilled) ODP sites (Fig. 1). These data were analyzed at the University of Texas Institute for Geophysics with SIOSEIS, a seismic processing software package, and GEOQUEST, a seismic interpretation software package. The interpretation software assists development of seismic stratigraphy by facilitating reflection horizon tracing and providing stratigraphic control at line cross-over points. The value of the system has been the output of digitized, interpreted stratigraphic data, as every trace is flagged with the depth-to-reflector horizon chosen in the interpretation. The seismic stratigraphy data set, therefore, is composed of thousands of data points, permitting accurate representation of the stratigraphy and statistically accurate averaging for further calculations. It is these data that form the basis of the seismic stratigraphy for this paper.

\section{Physical Properties}

Five sites on the northeastern margin of the Ontong Java Plateau were drilled during Leg 130 (Sites 803-807). These sites form a depth transect down the flank of the plateau (Fig. 1). In addition to continuous core recovery, downhole logging was conducted at all sites except Site 804. Data from two sites on the top of the plateau from DSDP drilling (Sites 289 and 586, $80 \mathrm{~m}$ apart) on Legs 30 and 89, respectively, are also available (Shipboard Scientific Party, 1975; Shipboard Scientific Parties of Legs 89 and 90, 1986).

Physical properties at each of the sites were measured in situ with downhole logging tools, and in the lab on discrete samples taken at frequent intervals within the cores after splitting. Downhole logging data pertinent to this study include compressional sonic velocity (both near and far fields), and lithodensity (gamma-ray flux). Discrete samples were taken from the cores every 0.75 to $1.50 \mathrm{~m}$ for saturated bulk density, porosity, grain density, and dry-bulk density measurements (see Kroenke, Berger, Janecek, et al. [1991] for details of the methods used to obtain these measurements). Longitudinal and transverse compressional sound velocities were measured directly within the unlithified sediment of the cores using the digital sound velocimeter (DSV) (Mayer et al., 1987; Courtney and Mayer, in press) or, on lithified sediment, with samples taken from the core, using the Hamilton frame (Boyce, 1973a, 1973b). Measurements were made every 0.75 to $1.50 \mathrm{~m}$ in the cores.

\section{OBSERVATIONS}

\section{Seismic Reflection Data}

The top of the Ontong Java Plateau is characterized by a thick sediment column, on the order of $1 \mathrm{~s}$ (two-way traveltime) from seafloor to acoustic basement, with numerous, closely spaced, parallel, continuous reflectors (Fig. 2, in back pocket). Many individual reflectors can be correlated throughout the seismic profiles on top of the plateau. Some reflectors are slightly higher in amplitude than surrounding reflectors, though amplitudes may decrease laterally. The distinction between high- and low-amplitude reflections become more apparent toward the edge of the plateau. The seafloor topography is flat to slightly undulating, reflecting basement topography. Acoustic basement is marked by several high-amplitude, discontinuous reflections underlying the sediment column.

The slope break between the plateau crest and its flank occurs at a water depth of $2250 \mathrm{~m}$, but no distinction in the echo character of reflectors in the sediment column between the slope and the plateau were observed until $2800 \mathrm{~m}$. Between this water depth and about $3375 \mathrm{~m}$, numerous vertical displacements and reflector disruptions were observed, resulting in an incoherent seismic facies (Fig. 2). These features are reflected in a rougher seafloor topography than on top of the plateau. The sediment column thins by about $30 \%$ through this depth range.

Reflectors become coherent again at about $3375 \mathrm{~m}$ water depth. The echo-character of the sediment section changes significantly as compared with the upper slope and plateau top (Fig. 2). Fewer reflection horizons in the sediment column and changes in dip direction between reflections, resulting in thinning and pinchout, were observed. Vertical displacements of reflections interpreted as faults are common. Recent and buried channels, slump scars and deposits, and fault displacements impart a rough seafloor topography.

On the lowermost portion of the slope, in water depths from 3800 to $4500 \mathrm{~m}$, acoustic basement is extremely irregular with a horstand-graben-like topography (Fig. 2). The nature of this basement morphology is thought to be fault controlled, possibly related to differential subsidence between the plateau and adjacent normal oceanic crust (Hagen et al., this volume). For conciseness, we will refer to these small, local basins as grabens and to the high areas between as horsts. Sediment reflectors are upturned and terminated at the sides of the horsts, and the sediment section thins markedly over them, making correlation of individual reflectors difficult. Distinct seismic facies are recognizable within the sediment column of the grabens.

Seismic reflection profiles in the Nauru Basin adjacent to the Ontong Java Plateau show a sediment section on the order of 0.2 to $0.5 \mathrm{~s}$ thick overlying the reverberant layer forming acoustic basement (Fig. 2). The horst-and-graben topography is not present in this region. Sediment reflections pinchout and outcrop away from the slope of the Ontong Java Plateau, making correlation of reflectors over any lateral extent difficult.

\section{Seismic Correlation}

Eight reflecting horizons, including the seafloor and basement, have been correlated throughout the available seismic reflection data, including correlation to each ODP and DSDP drill site. Figures $3 \mathrm{~A}$ and $3 \mathrm{~B}$ are two seismic stratigraphy interpretation profiles of the flank of the plateau (see Fig. 1 for the locations of these profiles). Figure 3A 


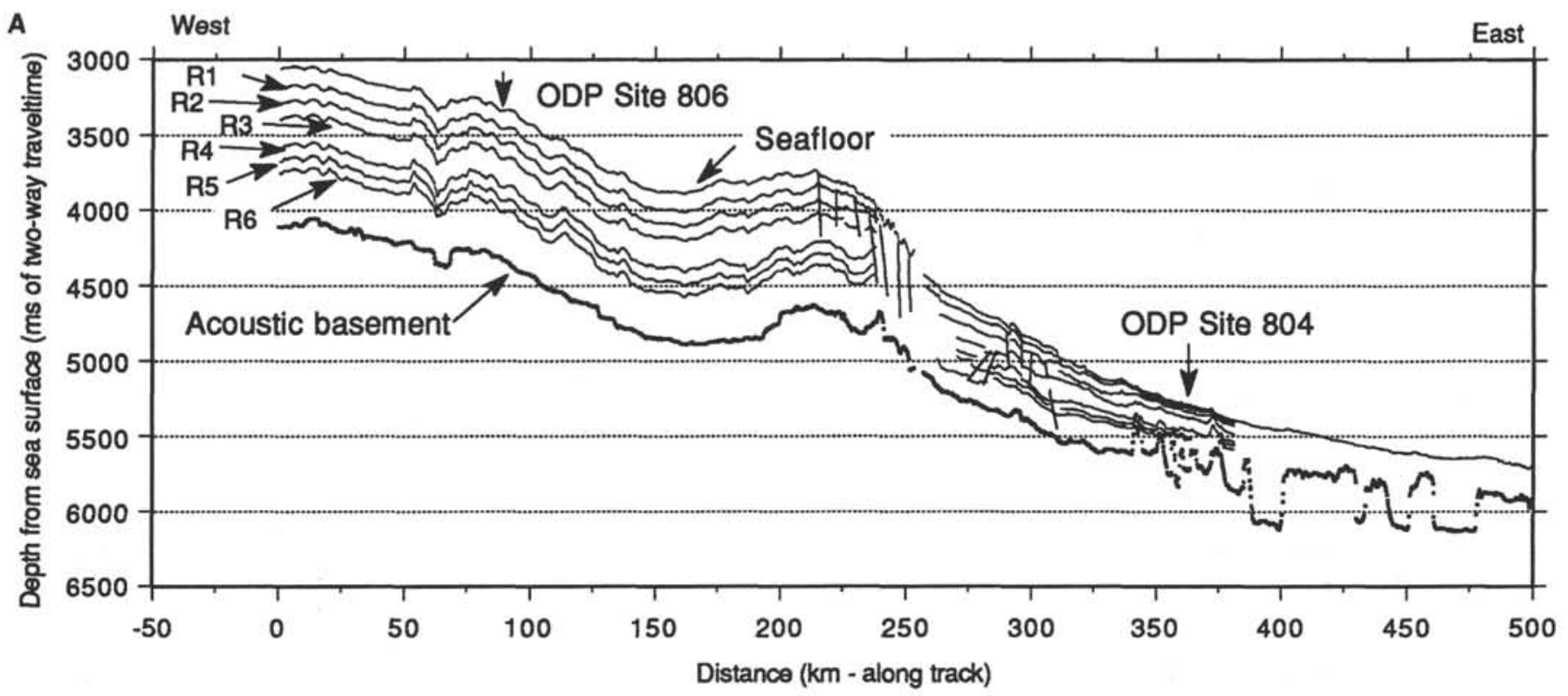

B

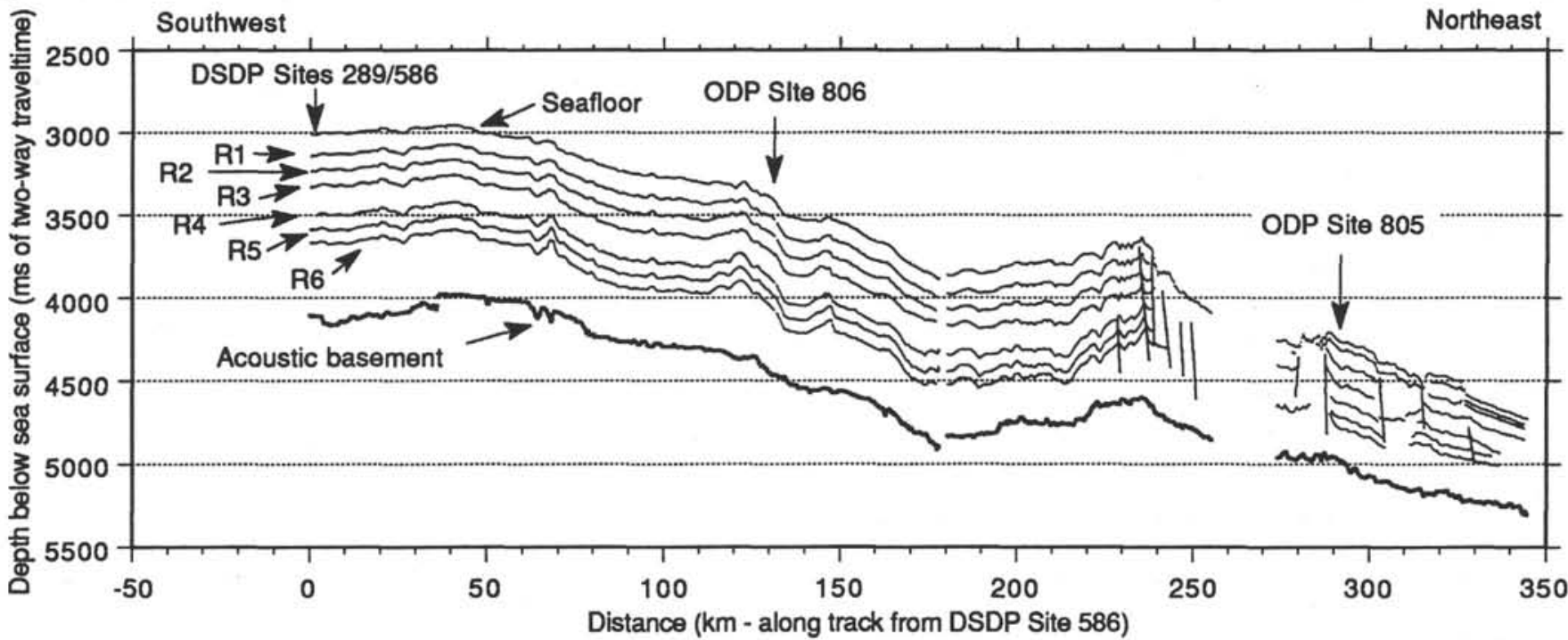

Figure 3. A. Interpreted seismic stratigraphy of the seismic section shown in Figure 2, extending from the top of the Ontong Java Plateau to its base in a west-east direction (see Fig. 1). B. Interpreted seismic stratigraphy extending part way down the flank of the plateau in a southwest-northeast direction (see Fig. 1). R1 to R6 represent the sediment reflection horizons correlated throughout the seismic data set. Vertical lines represent faults interpreted from the seismic data. Note the slope break occurs in about $3000 \mathrm{~ms}(2250 \mathrm{~m}$ ) water depth, but significant sediment column thinning begins at about $3700 \mathrm{~ms}(2800 \mathrm{~m})$ water depth. These plots were generated with digital data, output from GEOQUEST (a seismic interpretative software package). Each horizon represents about 2000 data points (every fifth trace of the seismic data).

is the interpretation of the seismic profile shown in Figure 2 (in back pocket). Bathymetry of the plateau flank dips and then rises again before plunging into the Nauru Basin. A sediment thickness plot (Fig. 4) shows that the sediment column thins most significantly over this rise and then continues to thin downslope. At the base of the flank, sediment thicknesses vary significantly because of infilling in the grabens. Figures 5 to 10 show the seismic section crossing and seismic stratigraphy at each of the drill sites. Figure 11 is a sediment thickness vs. water depth plot, summarizing the seismicstratigraphic data. From this figure, one can see that the sediment thins with increasing water depths. It shows that the entire sediment section has thinned $65 \%$ through these water-depth ranges (i.e., it is $35 \%$ as thick at the base of the plateau as at the top), and that thinning is most significant below $2900 \mathrm{~m}$ water depth. It is difficult to tell, however, from this figure where in the sediment column this thinning is occurring. Depths must first be converted to meters from traveltimes for calculations of the amount of thinning to become significant. This conversion can be accomplished through modeling the seismic response of the sediment column, which requires sediment physical properties information.

\section{Synthetic Seismograms}

\section{Physical Properties}

The two sediment physical properties that this paper is concerned with are compressional wave velocity and sediment bulk density. The product of these two properties is acoustic impedance; changes in impedance reflect sound, creating seismic reflections. Velocity and 


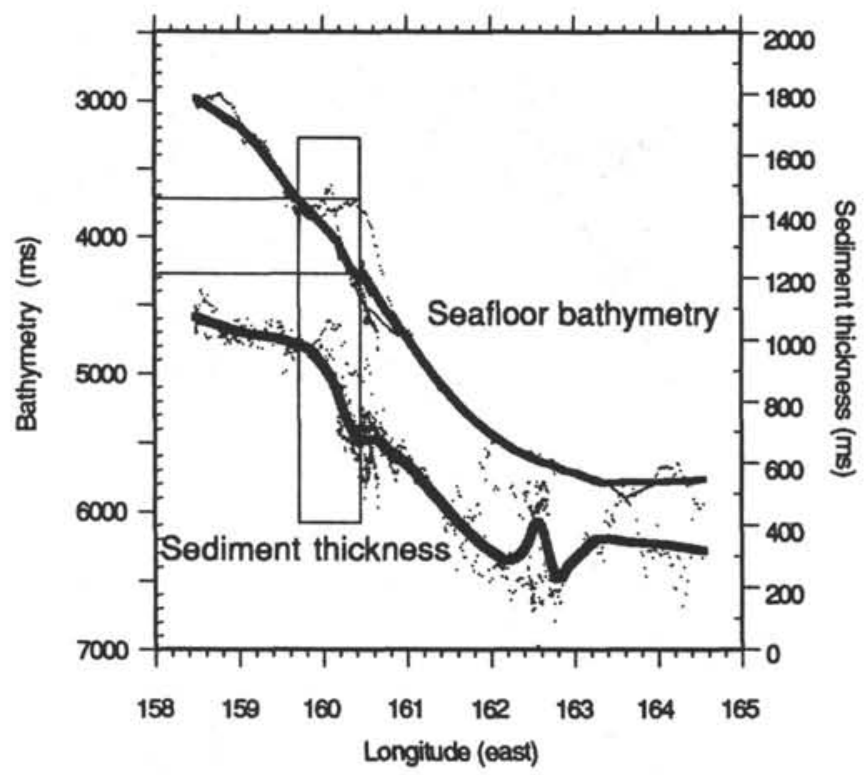

Figure 4. A profile of seafloor bathymetry (left-hand vertical axis) and sediment thickness (right-hand vertical axis), on the flank of the plateau, generated from the digital seismic stratigraphy data. Data are plotted with longitude as the $x$-axis, ignoring latitude; thus, true distance along track is not apparent. The data, perpendicular to the contours of the slope, are close enough to parallel a latitude line that a $15 \%$-weighted, smoothed curve through the data shows the profile, and the sediment thickness of the plateau, well. Note that the most extreme sediment thinning occurs between 2900 and $3225 \mathrm{~m}$ water depth.

density data were collected by discrete measurements made in the laboratory from recovered cores and through downhole logging with sonic velocity and gamma-ray density tools. Logging data are assumed to represent in-situ conditions. Laboratory data must be corrected to in-situ conditions of pressure and temperature.

\section{Density Corrections}

Removal of overburden pressure by the extraction of sediment core from in situ to the laboratory causes an increase in porosity in unlithified sediments (rebound porosity). A bulk-density measurement made on core material, therefore, must be corrected for porosity rebound. Porosity rebound can be simulated in a laboratory with a standard civil engineering test known as a consolidation test (Hamilton, 1971b; Das, 1983; Marsters and Manghnani, this volume). Marsters and Manghnani (this volume) conducted 19 of these tests on samples collected during Leg 130 and formulated the porosity rebound relationship for Ontong Java Plateau sediments as follows:

$$
\% \text { rebound }=4.67 \times 10^{-3} \mathrm{D}-1.97 \times 10^{-6} \mathrm{D}^{2} \text {, }
$$

where $D$ is depth in meters below seafloor.

The saturated bulk density of a sample is governed by the following relationship:

$$
\rho_{s a t}=\phi \rho_{f}+(1-\phi) \rho_{g}
$$

where $\phi=$ porosity, $\rho_{f}=$ fluid density (seawater), and $\rho_{g}=$ grain density (carbonate).

Correction of porosity to in-situ conditions with the porosity rebound equation then allows one to correct the bulk density to in-situ conditions. Corrected values of bulk density compare favorably to gamma-ray density values measured downhole (Fig. 12). The correc-

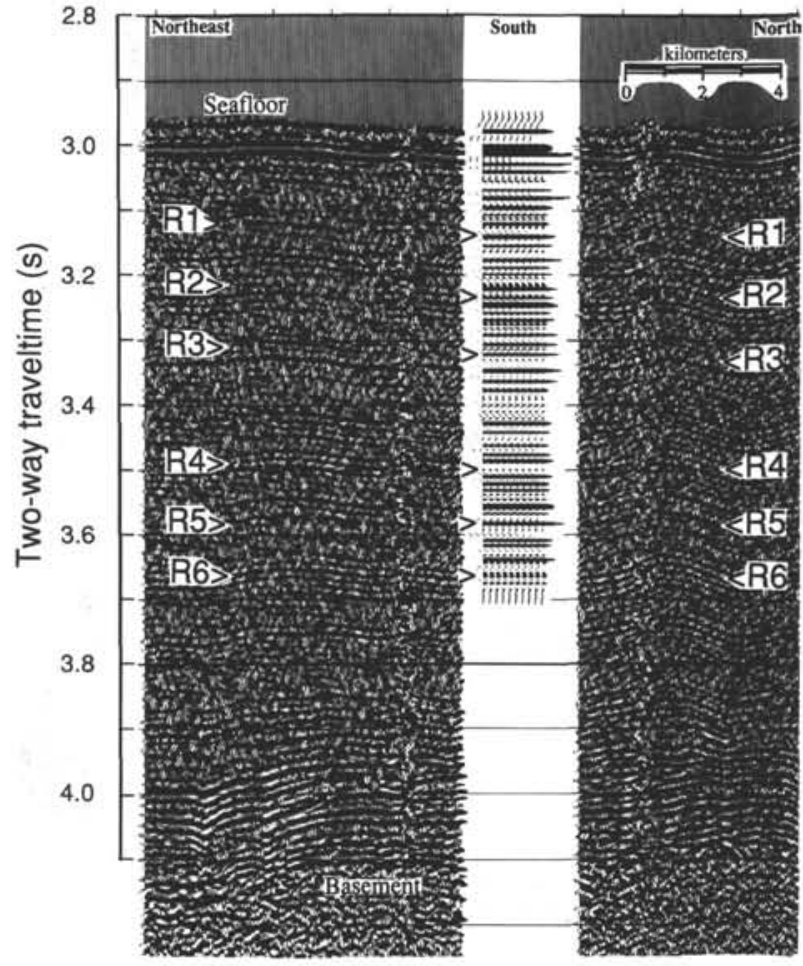

Figure 5. Seismic reflection profile on the Ontong Java Plateau, crossing over DSDP Sites 289 and 586. The data comprising this profile were collected on the Thomas Washington during Roundabout Leg 11. Note the lateral continuity, similar amplitude, parallel, gently undulating nature of the reflections, typical of the top of the plateau. The ship track turns over the drill site; hence, south is in the middle of the section (see Fig. 1, DSDP Site 289/586 crossing). R1 to R6 are the reflection horizons correlated throughout the seismic data set (see Fig. 3B). The synthetic seismogram generated from the impedance profile is shown in the middle of the section at the drill site.

tion, in fact, proves to be quite small $(2.7 \%$ decrease in porosity at $1000 \mathrm{~m}$ below seafloor).

\section{Velocity Corrections}

Compressional sound velocity in an isotropic material is a function of elastic properties and saturated bulk density of the rock/sediment, according to the following relationship (Wood, 1941; Hamilton, 1970):

$$
V^{2}=\frac{K+4 / 3 \mu}{\rho_{\text {sat }}},
$$

where $V=$ sonic velocity, $K=$ bulk modulus, $\mu=$ shear modulus, and $\rho_{\text {sat }}=$ saturated bulk density.

Mayer et al. (1985) have shown that correction of velocity to in-situ conditions in the central equatorial Pacific is possible by the relationship between laboratory velocity and laboratory porosity. Correction for porosity rebound merely shifts the curve, and corrected velocity values can be predicted from the adjusted curve. For the sediments of Leg 130, however, a good relationship between porosity and compressional velocity does not exist, implying that compressional velocity is not solely dependent upon porosity (Fig. 13) (Urmos et al., this volume). Porosity, therefore, could not be used to predict velocity. Hamilton et al. (1982) similarly found a poor relationship between compressional velocity and porosity and density for box core sediments on the Ontong Java Plateau. Other methods are required, therefore, to correct velocity to in-situ conditions. 


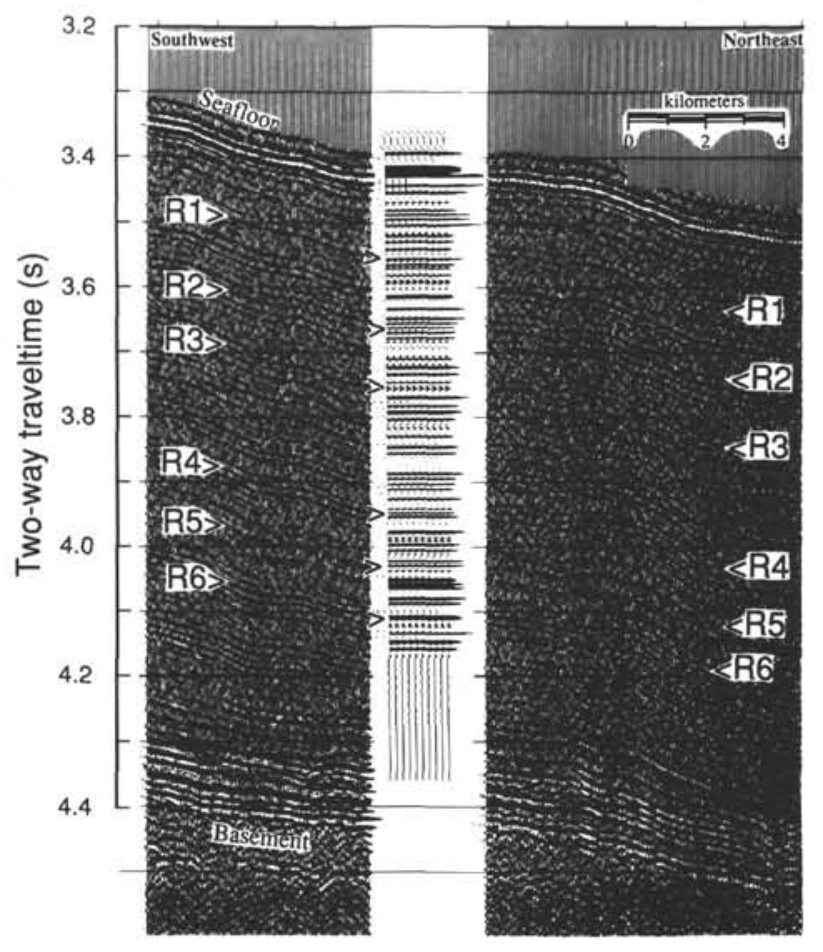

Figure 6. Seismic reflection profile on the Ontong Java Plateau crossing over ODP Site 806. These data were collected on the Thomas Washington during Roundabout Leg 11. This site is located on the uppermost part of the plateau flank in $2521 \mathrm{~m}$ of water (see Figs. 1 and 3A-3B). Note the similarity of the section with that of Sites 289/586 (Fig. 5). R1 to R6 are the reflection horizons correlated throughout the seismic data set. The synthetic seismogram is posted in the middle of the figure at the drill-site position.

The first correction to compressional velocity is for change in density, as shown above, as density appears in the denominator of Equation 3. Velocity must also be corrected to in-situ conditions of pressure and temperature. As shown by Wyllie et al. (1956) for rocks with rigidity, velocity is a function of pore fluid velocity and grain velocity:

$$
\frac{1}{V_{b}}=\frac{\phi}{V_{w}}+\frac{(1-\phi)}{V_{g}},
$$

where $V_{b}=$ bulk velocity, $V_{w}=$ velocity of pore fluid (seawater), $V_{g}=$ velocity of mineral grain, and $\phi=$ porosity.

Boyce (1976) developed the following correction for velocity to in-situ conditions in carbonate sediment of the Pacific Ocean, by assuming that the ratios of respective velocities were constant in the lab and in situ.

$$
V_{I I I}=\frac{\left(V_{3}-V_{2}\right)\left(V_{1}-V_{I I}\right)}{\left(V_{1}-V_{2}\right)},
$$

where $V_{1}=$ velocity of seawater at lab conditions, $V_{2}=$ velocity of mineral grain (calcite) at lab conditions, $V_{3}=$ velocity of sample at laboratory conditions, $V_{l}=$ velocity of seawater at in-situ temperature and hydrostatic pressure, $V_{I I}=$ velocity of calcite at in-situ temperature and hydrostatic pressure, and $V_{I I}=$ velocity of sample at in-situ temperature and hydrostatic pressure.

The velocity of seawater can be calculated based on temperature, salinity and hydrostatic pressure using equations developed by Wilson (1960) derived from measured sound speed data. The temperature downhole is calculated using a geothermal gradient of $0.044^{\circ} \mathrm{C} / \mathrm{m}$. This value was derived from heat flow measurements on the Ontong Java Plateau reported in Langseth et al. (1971). The velocity of calcite

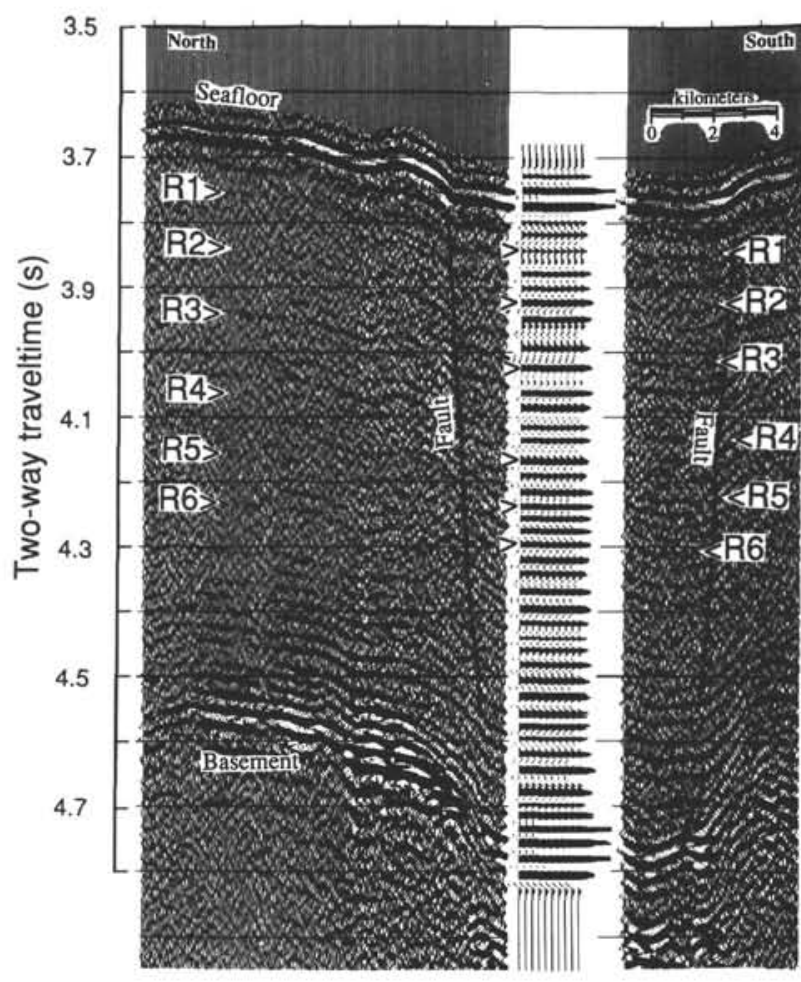

Figure 7. Seismic reflection profile on the Ontong Java Plateau crossing over Site 807, in $2804 \mathrm{~m}$ water depth (see Fig. 1). These data were collected on the JOIDES Resolution during Leg 130. The data are of lower frequency content than the Thomas Washington data, making it difficult to correlate with the Thomas Washington seismic stratigraphy. To the south and north of Site 807, the sediment thickness is the same as on top of the plateau and reflections are roughly similar in character to those of the top of the plateau. Site 807 , however, is located in a depression in acoustic basement, corresponding to a thicker sediment section. Some disruptions in reflections are associated with this basement low. R1 to R6 are reflection horizons correlated with the traced reflection horizons from the Thomas Washington seismic data. The synthetic seismogram is posted in the middle of the section at the position of the drill site. The seafloor return from the field seismic data was used as the source wavelet in the convolution to generate this seismogram, because the seismic source wavelet was obviously significantly different from the source used during the Thomas Washington survey.

is assumed to remain constant with depth and temperature at $6450 \mathrm{~m} / \mathrm{s}$ (Boyce, 1976).

Application of these corrections to laboratory-measured velocities produces a downhole curve of velocity vs. depth that shows significantly lower velocities than the logging velocity curve (Fig. 14). In other words, the laboratory-measured velocity, corrected by the methods suggested by Mayer et al. (1985) and Boyce (1976), do not compensate for in-situ conditions, in this depositional environment, when compared with logging velocity data. We think that this disparity is likely a function of elastic moduli that appear in velocity Equation 3. Bulk moduli $(K)$ and shear moduli $(\mu)$ are not accounted for in the above corrections. That is to say, the ratios of velocities are not constant as Boyce (1976) assumed in his corrections. One would expect that increasing overburden pressure would tend to increase values of $K$ and $\mu$, as it would tend to enforce sediment grain-to-grain contacts. Urmos et al. (this volume), in attempting to correct velocity data to in-situ values, have reached many of the same conclusions.

Rigidity effects on velocity are especially important in the foraminifer-rich sediment considered in this study, as Fulthorpe et al. (1989) also noted in their seismic studies of the Ontong Java Plateau. Foraminifer tests are hollow spheres with intraparticle porosity, so the 


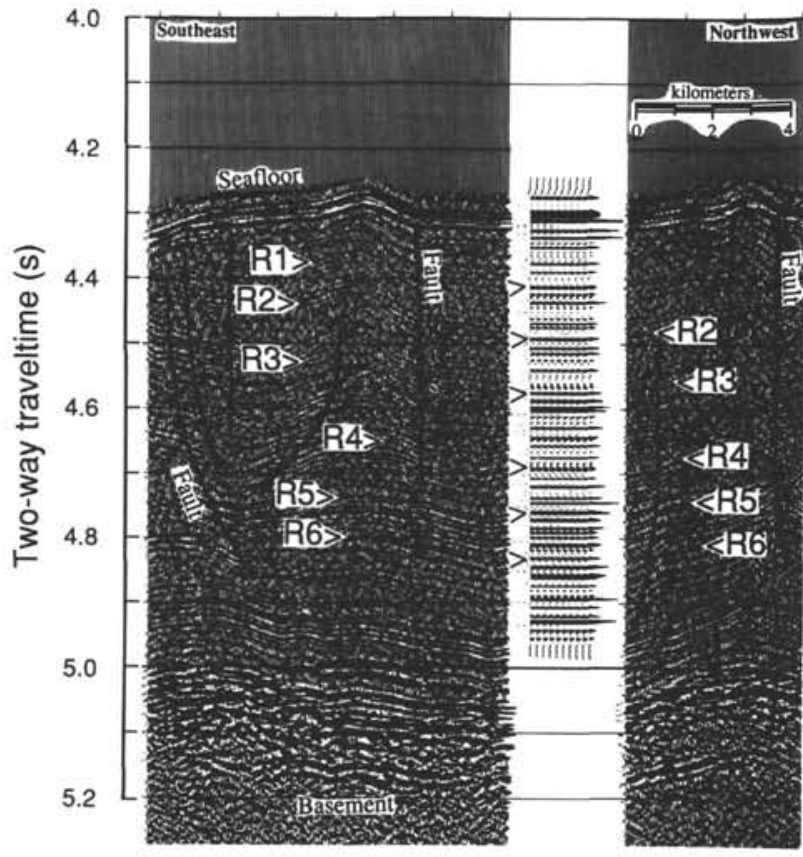

Figure 8. Seismic reflection profile on the Ontong Java Plateau crossing over Site 805 . These data were collected on the Thomas Washington during Roundabout Leg 11. The site is located in $3188 \mathrm{~m}$ water depth (see Figs. 1 and 3B). The sediment column has thinned $25 \%$ compared with Site 806 . The reflection profile is similar in character to sections higher on the plateau, although some reflections are of slightly higher amplitude. R2 to R6 are the correlated reflection horizons, traced throughout the seismic data set. Some evidence of faulting is present, noted by a displacement of reflectors within the sediment column. A synthetic seismogram is posted in the middle of the figure at the drill site position.

nature of the grain-to-grain contact can be changed without significantly decreasing total porosity. For example, experiments by Laughton (1957), in which he simultaneously measured consolidation and velocity on foraminifer ooze, found that a $5 \%$ change in porosity resulted in a $64 \%$ change in velocity ( 3.05 to $1.96 \mathrm{~km} / \mathrm{s})$, which he mainly attributed to a change in grain-to-grain rigidity (shear modulus). Hamilton et al. (1982) also suggested that, for the Ontong Java Plateau, shear rigidity $(\mu)$ was the dominant cause of velocity variations because the density $(\rho)$ and bulk modulus $(K)$ terms of Equation 3 tend to cancel. Corrections to elastic moduli, however, cannot be readily applied because they vary significantly between sediment types and geologic setting and because little information is available on elastic and viscoelastic properties of water-saturated, uncemented marine sediments at low pressures (see Hamilton, 1971a, 1971b, $1972,1974,1980$ ).

To adjust for differences observed in lab and log velocity data, laboratory measurements within the ooze interval were further corrected to logging velocity curves in the ooze interval. This correction is accomplished by determining a best-fit linear regression curve through logging velocity and lab velocity data (Fig. 15). The regression through the log data is forced through the same point of origin as the lab data regression because at the seafloor no rigidity effects exists (and the lab data is already corrected for temperature). Lab velocity data is then adjusted so the trend of lab values is equivalent to the trend of log velocity values. A different curve was calculated at each drill site to account for differing sediment characteristics at each site. The final corrected laboratory compressional wave velocity measurements are assumed to represent in-situ conditions (Fig. 16).

One should note that logging compressional velocity values are not considered to be correct for the ooze intervals, as the coring process tended to enlarge the diameter of the drill hole beyond the

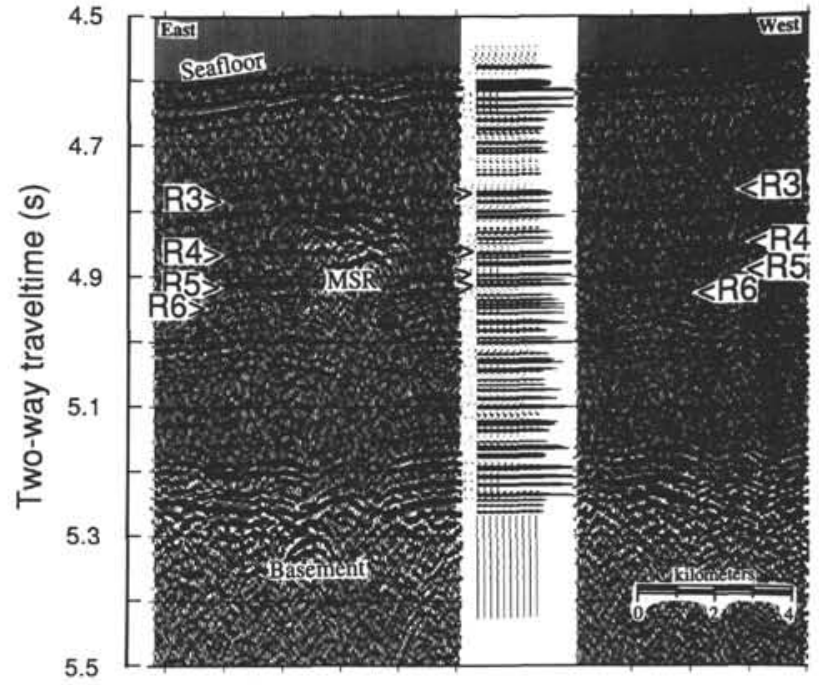

Figure 9. Seismic reflection profile on the Ontong Java Plateau crossing over Site 803. These data were collected on the Thomas Washington during Roundabout Leg 11. The site is located in $3410 \mathrm{~m}$ water depth (see Figs. 1 and $3 \mathrm{~A}$ ). The sediment column has thinned by about $40 \%$ compared with the top of the plateau. The profile shows parallel reflectors at the site. Higher amplitude reflections can be seen in the middle of the section and a mid-section reverberation (MSR) layer is observed next to the site. These features are common within the sediment section at about this water depth on the flank of the plateau and have been observed elsewhere throughout the Pacific (Houtz and Ludwig, 1979; Shipley et al., 1985). High amplitudes of reflection wavelets comprising these features suggest high impedance contrasts with surrounding sediment. They have been interpreted as volcanic sills and as diagenetic horizons (Kroenke, 1972; Houtz and Ludwig, 1979; Shipley et al., 1985). In this case, the MSR occurs at the exact horizon of a Miocene hiatus (between the R3 and R4 reflection horizons). An ash layer was also observed at about the same depth as the MSR, though the relationship between the two is uncertain. R3 to R6 are the reflection horizons correlated throughout the seismic data set. A synthetic seismogram is posted in the middle of the section at the drill site position.

accurate range of the transducers mounted on the logging string. In other words, the velocities measured with the logging tool integrate velocities of the water surrounding the tool as well as the sediment. Through much of the ooze interval, the diameter of the holes is not known because the holes are wider than the maximum extension of the caliper tool. A power spectral density plot of logging $P$-wave velocity, and gamma-ray density, through the ooze interval at Site 806 shows extreme dominant power at a wavelength of $9.5 \mathrm{~m}$ and two of its harmonics ( 4.75 and $3.17 \mathrm{~m}$ ) (Figs. 17A-17B). This periodicity is likely a coring artifact, as it is precisely the length of the advanced hydraulic piston core (APC). The power spectrum suggests that this frequency component would completely mask any real components in any mathematical operation that involved this data.

This coring disturbance is most pronounced at Site 806 , but it is also recognized at each Leg 130 site. In spite of these inaccuracies in the high-frequency component of the data, we think that the data trends are accurate and represent in-situ conditions, and it is these trends to which the laboratory-measured velocity data are being corrected. We also think that the corrected laboratory data of both velocity and density are more accurate than the logging data over the ooze interval. These data, therefore, are used for ooze intervals and are merged with logging data at the ooze/chalk transitions (between 240 and $350 \mathrm{mbsf}$ ). Downhole velocity and density profiles are, therefore, sampled with discrete measurements with a maximum sample spacing of about $0.75 \mathrm{~m}$ for the laboratorymeasurement portion, and $0.15 \mathrm{~m}$ for the log-measurement portion 


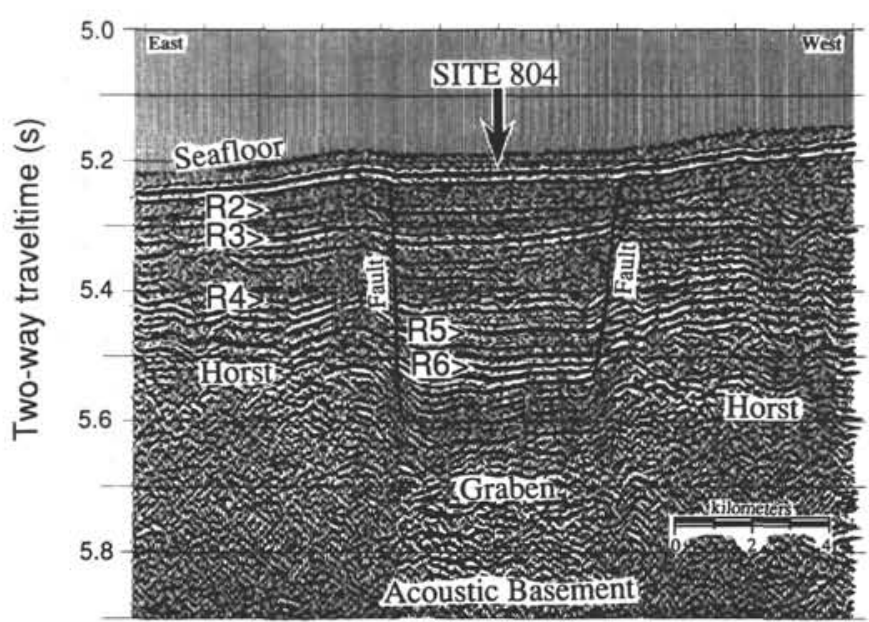

Figure 10. Seismic reflection profile on the Ontong Java Plateau crossing over Site 804 collected on the Thomas Washington during Roundabout Leg 11. This site is located in $3862 \mathrm{~m}$ water depth, within a basement depression, thought to be a graben structure (Hagen et al., this volume). The sediment section is about half as thick as on top of the plateau. Reflections vary greatly in amplitude with depth, and correlation outside of the depression is difficult. Evidence of active sedimentation exists in this isolated basin, with onlap and pinchout of the reflections against its walls. R1 to R6 represent the correlated reflector horizons. No downhole logging was conducted at this site, so no data exist for generation of a synthetic seismogram.

of the curves. The product of velocity and density is impedance; thus, these profiles provide the basis of the reflection coefficient series for seismogram modeling.

\section{Correlation to Seismic Data}

It is necessary to correlate Leg 130 drill sites to the acoustic stratigraphy to examine the response of the seismic signal to changes in physical properties within the sediment column. The most critical and difficult step in applying stratigraphic significance to seismic data is the transformation of sub-bottom depth information to traveltime information, which requires an exact knowledge of the in-situ velocity. This domain transformation can be accomplished through the generation of synthetic seismograms.

Synthetic seismograms model the interaction between a seismic wavelet and a given well-constrained geologic model. With an accurate representation of the seismic source wavelet and an accurate and detailed picture of subsurface geologic variations, the synthetic seismogram should provide a record of their interactions. The geologic model is the Earth's reflection series, which is essentially the change in acoustic impedance with depth, impedance being the product of compressional wave velocity and bulk density. The synthetic seismogram is produced by mathematically convolving the source function (in this case the signal produced with a $1.31 \mathrm{~L}$ water gun) with the reflection coefficient curve (change in impedance) at the site.

At each drill site on the Ontong Java Plateau, a synthetic seismogram was generated from merged log and lab velocity and density data, except for Site 804, for which no logging data exists. Analyses of the field data showed that the source function was of lower frequency content $(0-100 \mathrm{~Hz})$ than the calibrated hydrophone test performed during the same cruise that produced the source function used in the convolution $(0-300 \mathrm{~Hz})$. As a consequence, the synthetic seismograms were bandpass-filtered $(0-100 \mathrm{~Hz})$ to approximate the frequency content of the seismic data. Figures 5-10 show the results of synthetic models with correlation to the seismic reflection data over each site. We also found that a static shift in velocity values of -30 $\mathrm{m} / \mathrm{s}$ was required to accomplish the appropriate traveltime-to-depth conversion for horizontal correlation of the synthetic seismogram to field seismic data. This correction implies that the logging velocity tool overestimates true in-situ velocity by $30 \mathrm{~m} / \mathrm{s}$.

Figure 18 is a cross-plot of the synthetic-to-seismic correlation results shown in Table 1. This figure shows that correlations at each site all fall on a single curve, implying that a single velocity-depth function applies to all the sediments of the Ontong Java Plateau, regardless of the water depth in which they were deposited, or their age, or state of induration. The equation of a second-order polynomial curve fit through this data allows the conversion of traveltime on the seismic section to depth in meters below seafloor, or vice versa. Figures 19A and 19B show the results of site-to-site correlations based on the seismic stratigraphy and synthetic seismogram depth conversions, as compared with results of site-to-site correlation based on an inverse-signal correlation technique of logging density and resistivity curves (Lyle et al., this volume). These data of Lyle et al. (this volume) provide a means of checking seismic stratigraphic correlations and the conversion of traveltime to depth. The results of these comparison plots show reasonable agreement between the correlations of Lyle et al. (this volume) and those based on seismic stratigraphy.

\section{DISCUSSION}

Three striking changes occur in the character of seismic profiles from the top of the Ontong Java Plateau ( $2000 \mathrm{~m}$ water depth) to the Nauru Basin (4500 $\mathrm{m}$ water depth): (1) a drastic decrease in sediment thickness (about 75\%); (2) the loss of continuous, parallel reflectors; and (3) development of distinct seismic facies (i.e., intervals in profile of high-amplitude, continuous reflections, overlying or underlying intervals of lower amplitude or incoherent reflections) with increasing water depths, as opposed to the top of the plateau, which demonstrates one sequence of similar echo-character throughout the sediment column.

The seismic character of low-amplitude, laterally continuous, and largely parallel reflectors across the top of the Ontong Java Plateau and down to a water depth of about $2800 \mathrm{~m}$ water depth are consistent with the uninterrupted blanket of post-upper Oligocene pelagic sediments described for Sites 289, 806, and 807 (Shipboard Scientific Party, 1971; Kroenke, Berger, Janecek, et al., 1991). The cause (or causes) of this echo-character is not entirely clear. Mayer et al. (this volume) interpret grain-size fluctuations as the dominant factor in determining changes in bulk density as observed in gamma-ray attenuation and porosity evaluator (GRAPE) data. The grain-size distribution naturally affects the nature of grain-to-grain contacts. We expect, therefore, that sediment grain size also greatly influences compressional velocity. Because grain size can affect density and velocity, then grain-size fluctuations may account, at least in part, for seismic reflections.

In the pelagic environment of the Ontong Java Plateau, sediment grain-size distribution can be affected in two ways: (1) productivity/preservation conditions, in which the size distribution is determined by the sizes of tests produced and the amount of selective dissolution that has affected these particles; and (2) resedimentation, in which pelagic sediment is syndepositionally or postdepositionally affected by sedimentation processes, namely, winnowing on the plateau top. Wu and Berger (1991) and Mayer et al. (this volume) consider winnowing to be an important process on top of the plateau, related to paleoceanographic events. Aside from a slight thickening of seismic units toward the edges of the plateau, which will be discussed below, there is little evidence in the seismic reflection data for large-scale winnowing. Reflectors on top of the plateau are parallel and continuous over long distances (hundreds of kilometers). If winnowing has been an important process, it has not disrupted the sediment column, produced any visible bedforms, or significantly eroded sediment on top of the plateau. The seafloor topography largely reflects basement morphology, in spite of the fact that the sediment column is over $1000 \mathrm{~m}$ thick. Seismic evidence, therefore, 


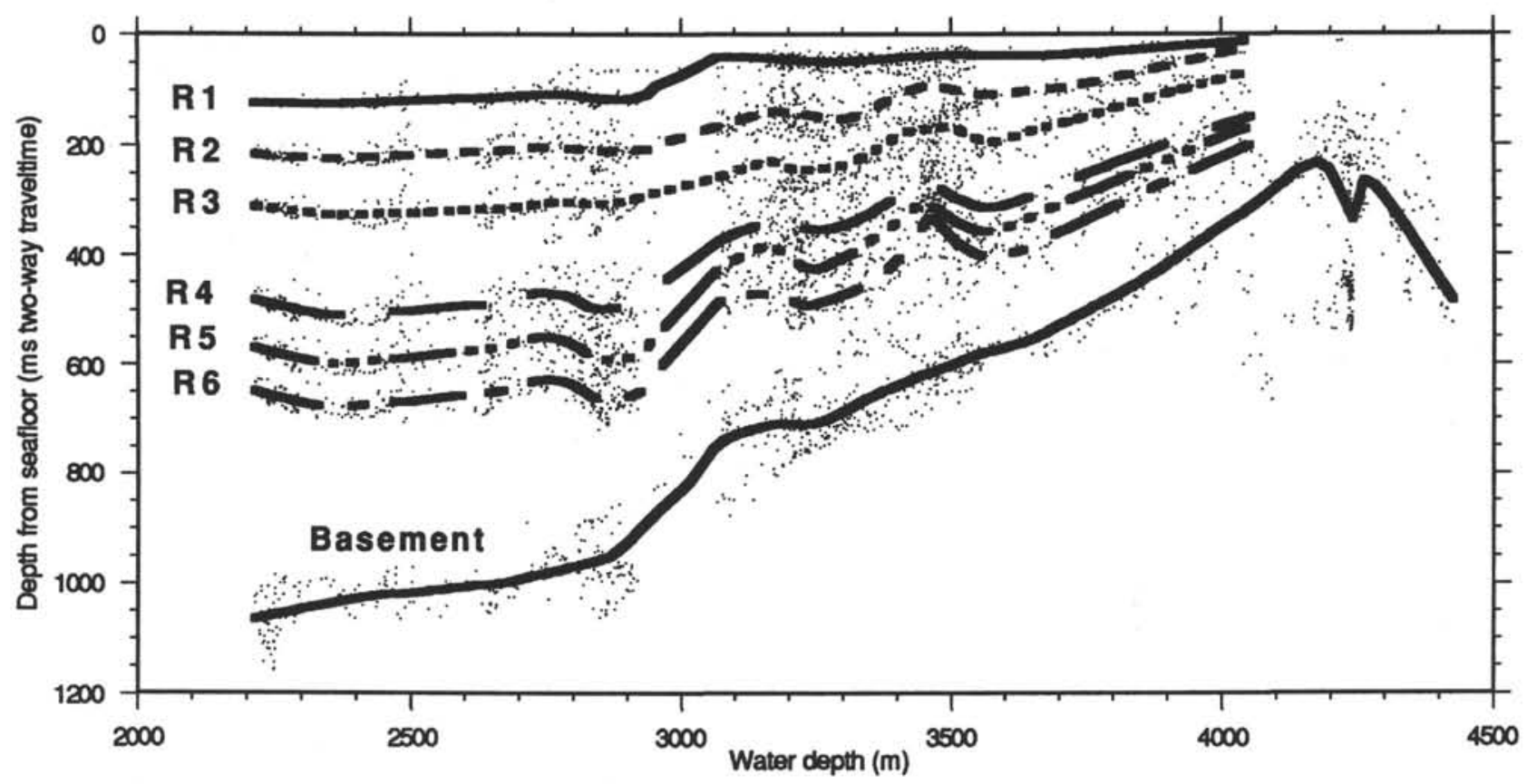

Figure 11. Sediment thickness vs. water depth. This plot shows the thickness from the seafloor to each of the reflection horizons at given water depths. The entire digital seismic stratigraphy data set was used to produce these plots, not just a single line; hence, the scatter of points. A $15 \%$-weighted, smoothed curve was used to fit the data for each horizon.

would support the theory that productivity/preservation changes are the mechanisms responsible for grain-size fluctuations on top of the plateau rather than sedimentation processes.

Evidence exists, however, within the seismic reflection and core data that resedimentation processes are active on the flank of the Ontong Java Plateau. Evidence of faulting and mass wasting that has been interpreted from the recovered sediment (Kroenke, Berger, Janecek, et al., 1991) can account for loss in reflector continuity, and the development of seismic facies, on the flank of the plateau. This evidence is especially apparent in the incoherent section between 2900 and $3300 \mathrm{~m}$ water depth (Fig. 2), which coincides with the steepest slope and the greatest amount of sediment thinning on the flank.

Site 807 is located in $2800 \mathrm{~m}$ water depths within a slight basement depression. Seismic reflection profiles at the site show reflector displacements and incoherent reflections within the sediment associated with this downdrop in basement. Sediment cores demonstrate a number of intervals within which microfaults are common, from as shallow as 49 mbsf to the base of the sediment section (Kroenke, Berger, Janecek, et al., 1991). These features are likely associated with reflector discontinuities in the seismic profile. Below about $1116 \mathrm{mbsf}$ (lower Eocene), numerous intervals bearing suspended clasts up to $0.05 \mathrm{~m}$ in diameter were observed. These clasts typically contain older nannofossil assemblages than the matrix (Kroenke, Berger, Janecek, et al., 1991). These zones are thought to represent erosion of outcropping material further upslope and transport into the basin by debrisflow processes. Overlying these clast-bearing sediments is a 35-m-thick limestone interval containing well-sorted foraminifer sand layers interpreted as possible turbidites. In addition, most of the claystones and radiolarian siltstones that overlie basement are interpreted as turbidites (Kroenke, Berger, Janecek, et al., 1991). Seismic stratigraphy analyses show that the unit between the R6 horizon and acoustic basement is greatly overthickened at this site relative to Site 586 (Fig. 20).

There is evidence also for active resedimentation processes throughout much of the flank of the plateau. Thinning of the sediment column with depth can be explained by increased carbonate dissolution with water depth. Drilling results have shown that the sediment column at each of the sites down the flank of the plateau is composed of $80 \%-90 \%$ carbonate material (Kroenke, Berger, Janecek, et al., 1991). Experiments by Berger (1967, 1968, 1970), Wu and Berger (1991), and Wu et al. (1991) have demonstrated that the present-day lysocline and CCD of the Pacific Ocean and of the Ontong Java Plateau in particular, lie at about 3500 and $4000-4500 \mathrm{~m}$ water depths, respectively. If present conditions have prevailed over the last $40 \mathrm{~m} . \mathrm{y}$., then the sediment thickness would remain constant with depth down to about $3500 \mathrm{~m}$. It would drop off suddenly at $3500 \mathrm{~m}$ and, by definition of the CCD, should be nonexistent below $4500 \mathrm{~m}$ (i.e., no carbonate preservation). The profiles of sediment thickness (Figs. 4 and 11), however, show that the sequence begins to thin significantly at about $2900 \mathrm{~m}$ water depth $(3900 \mathrm{~ms})$. The sediment section continues to thin but is still about $25 \%$ as thick as the top of the plateau by $4500 \mathrm{~m}$ water depth. It is still composed of about $70 \%$ carbonate material at this depth (Berger et al., 1977). Differences in this profile from the theoretical described above suggests that either the lysocline and CCD were not in the same position in the past as they are at present, and/or the profile has been significantly altered by masswasting events. Sediment failure would transport material from the upper portion of the plateau flank to below the CCD. Rapid deposition resulting from mass failures also would ensure isolation of sediment from the water column to prevent significant sediment dissolution. In this way, mass-wasting processes modify sediment distribution down the flank.

Evidence exists in the seismic reflection profiles from most of the plateau flank below a water depth of $2800 \mathrm{~m}$ for scarps, faults, erosional channels, slump blocks and reflector pinchouts, and discontinuities indicative of mass-movement events. Though drilling sites were chosen in an attempt to avoid such features, sediments recovered at Sites 805 and 803 exhibit evidence of microfaulting (Kroenke, Berger, Janecek, et al., 1991), which may be attributed to larger scale faulting.

The fact that sediment failures are in the depth range between the lysocline and the CCD suggests that dissolution may have played a role in their genesis. It is possible that carbonate material deposited on the slope below the lysocline is removed or weakened through time 


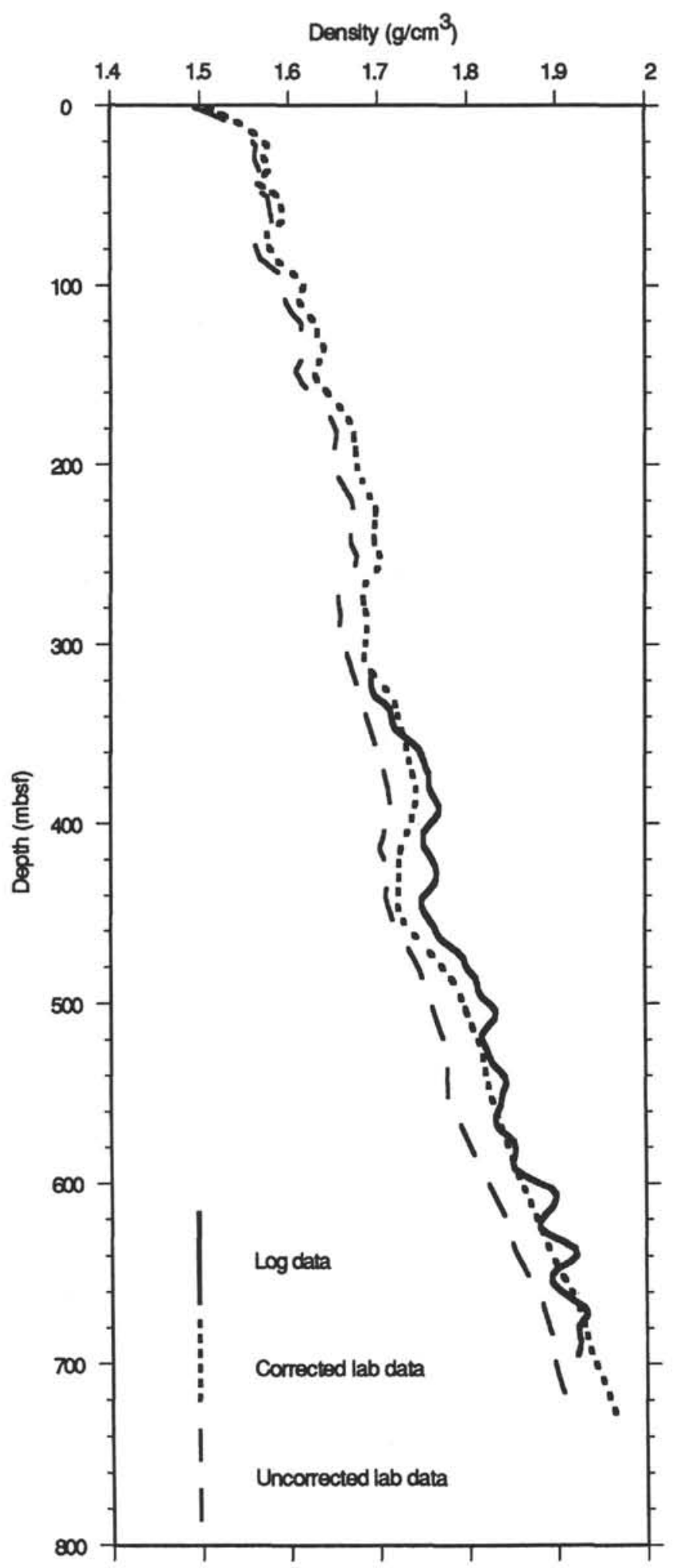

Figure 12. Comparison plot of uncorrected laboratory density data, corrected laboratory density data (using Marsters and Manghnani [this volume] correction for porosity rebound), and logging gamma-ray density vs. water depth. The lines are 5\%-weighted, smoothed curves through the data. The correction proves to be small but accurate, assuming the logging values represent in-situ conditions.

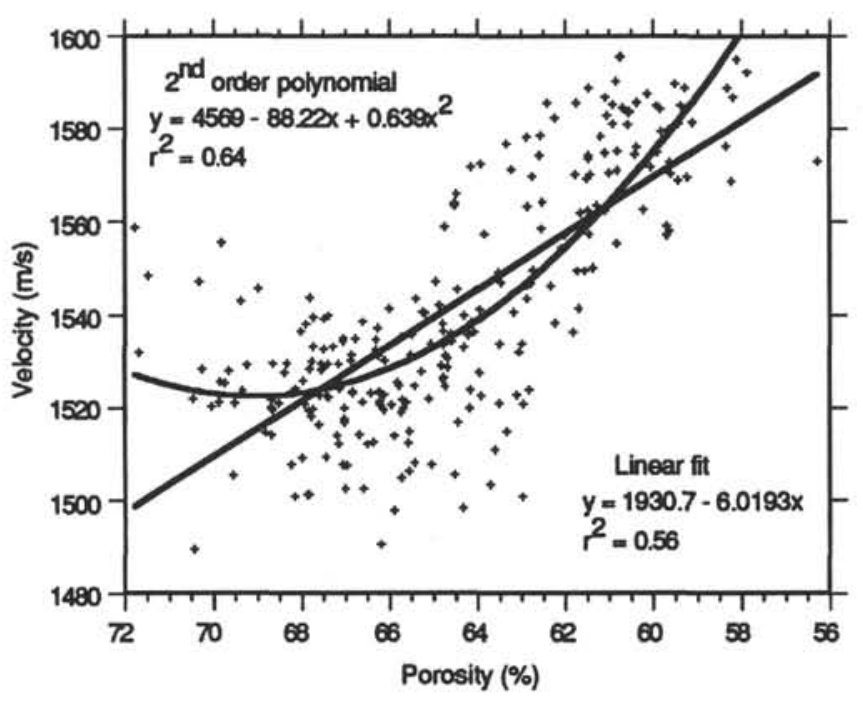

Figure 13. Plot of laboratory measured compressional velocity $(P$-wave velocity) vs. porosity for Site 806 (0-350 mbsf). The poor correlation coefficients $\left(r^{2}=0.56\right.$ for a linear fit and 0.64 for a second-order polynomial fit) show that velocity depends very little on porosity. The deeper sites show even poorer correlation between these parameters. This plot is used as an example to show that porosity cannot be used to "predict" velocity, to find a correction for velocity to in-situ conditions for Ontong Java Plateau sediments, as Mayer et al. (1985) did in the central equatorial Pacific.

by dissolution. This process removes support for sediment further upslope, causing sediment failures. This dissolution and removal of support is known as dissolution undercutting, as described by Berger and Johnson (1976). Earthquake ground accelerations, which occur frequently with the collision of Ontong Java Plateau and Solomon Arc on the western side of the plateau (Kroenke, 1972; Kroenke et al., 1986) further add to the frequency of sediment mass failures and may be the triggering mechanism for sediment that has undergone dissolution undercutting.

Toward the base of the plateau flank (i.e., $3800-4500 \mathrm{~m}$ water depth) strong evidence for resedimentation processes is apparent on the seismic reflection profile. The sediment column is complicated by the rough acoustic basement morphology, comprised of a series of small basins interpreted as grabens (Hagen et al., this volume) (Fig. 2). Reflectors truncate and upturn at the sides of these basins, probably resulting from either differential compaction or sediment offlap or onlap during deposition. The truncation of reflectors at the surface above basement highs suggests that seafloor erosion is taking place and the depocenters are these small grabens. Shipley et al. (1989) argue that basin filling is an active sedimentation process in the deep sea of the equatorial Pacific. Basin filling comprises particle-by-particle downslope movement of sediment occurring syndepositionally, as well as postdepositional erosion, downslope creep, slumping, and local turbidity current processes that move sediments from the slopes and highs into local lows (Johnson and Johnson, 1970; Moore and Heath, 1967; Mudie et al., 1972). Basin filling produces deposits characterized by onlapping onto surrounding highs (Shipley et al., 1989).

Site 804 was located within one of these basement grabens (Fig. 10). Kroenke, Berger, Janecek, et al. (1991) reported that the lower Pliocene contained mixed assemblages of older fauna, indicating sediment reworking; numerous dipping color bands with associated microfaults were observed; sorted and graded beds interpreted to be turbidites were apparent in the late and middle Miocene; and between 187 and 207 mbsf, an interval of highly disturbed sediment, interpreted as a slump deposit, was noted. This slump interval corresponds with a hiatus between 197.1 and $206.8 \mathrm{mbsf}$ in the early to middle Miocene (14.7-20.8 Ma). 


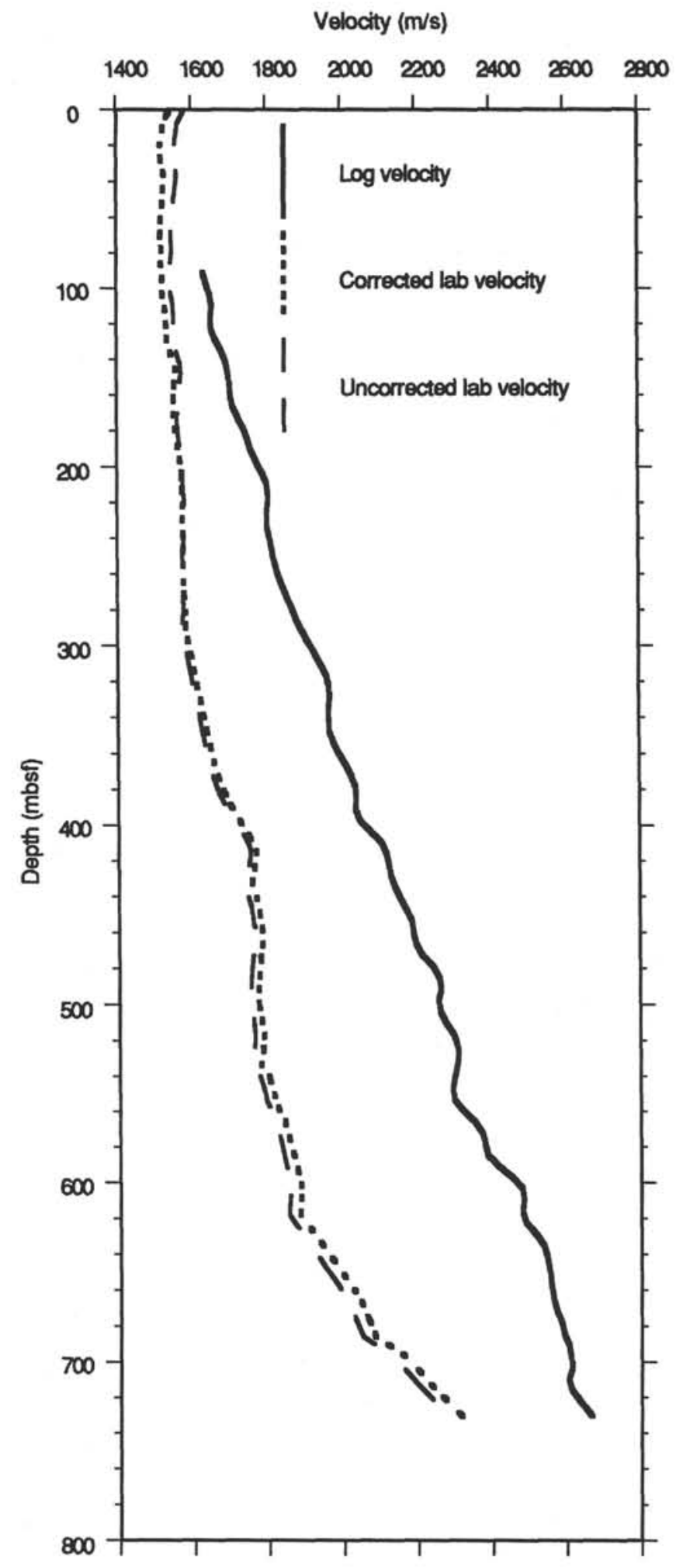

Figure 14. Plot of uncorrected and corrected laboratory $P$-wave velocity (corrected for density changes resulting from porosity rebound and in-situ conditions of pressure and temperature) and logging velocity vs. depth below seafloor. This plot is used as an example to show that even with corrections, laboratory velocity do not accurately represent assumed in-situ conditions.
On the extreme lower end of the flank of the Ontong Java Plateau and into the Nauru Basin, seismic reflection data show distinct differences in reflection patterns (Fig. 2). Reflectors tend to pinch out and truncate against the seafloor. We interpret that the appearance of the reflection profile is a result of active sedimentation, particularly turbidity current activity, bringing material from the plateau into the basin. The fact that carbonate material exists here at all, below the $\mathrm{CCD}$, would support this interpretation.

Although faulting, mass wasting, and other resedimentation processes can account for reflector discontinuities and the development of seismic facies, and they can account for the redistribution of sediment, they cannot account for the degree of sediment thinning with increasing water depth down the flank of the plateau, which is the most striking feature of the seismic reflection data. Thinning is caused by the dissolution of carbonate material below the lysocline. It is, therefore, dependent upon the position of the lysocline (water depth) and on the dissolution gradient between the lysocline and the CCD. Because sediments of the Ontong Java Plateau are composed almost entirely of carbonate material, their distribution is sensitive to the lysocline position, the dissolution gradient, and changes through time of these parameters.

Figures $3 \mathrm{~A}-3 \mathrm{~B}, 4,11$, and 20 and Tables 1 and 2 show where and when thinning is taking place in the sediment column. In Figure 20, the greatest degree of thinning, observed at Sites 803 and 805 , appears to have occurred between the R3 and R4 horizons (middle Miocene), and between the R5 and R6 horizons (Oligocene-early Miocene). The R3 to R4 thinning corresponds to a Miocene hiatus (15.4-21.8 Ma) at Site 803, and the R5 to R6 thinning correlates with a condensed section in the late Oligocene (23.7-28.2) at Site 803 (Kroenke, Berger, Janecek, et al., 1991). In this way, seismic reflection data are reiterating what is observed from the core evidence.

It is interesting to note that the sediment column between the R1 and R5 reflectors (early Miocene to Pliocene) is thicker at Site 806 relative to Site 586 , and is thicker between the R2 and R3 reflector (late Miocene) at Site 805, relative to Site 586. Reflector correlations to these sites have been accomplished with confidence and agree reasonably well with the correlations of Lyle et al. (this volume). Given that the correlations are correct, this apparent overthickening can be explained by one of two mechanisms:

1. A slight latitudinal gradient is present between Site 586 at $0.29^{\circ} \mathrm{S}$, Site 806 at $19^{\prime} \mathrm{N}$, and Site 805 at $1^{\circ} 14^{\prime} \mathrm{N}$. It is possible that this latitudinal gradient corresponds to a latitudinal surface-water productivity gradient. At present, the most productive water is slightly offset from the equator at about $2^{\circ} \mathrm{N}$ (Berger et al., 1988; Berger, 1989).

2. The second explanation for the overthickening involves winnowing processes that might have removed sediment from the shallowest parts of the plateau to be deposited at the top of the flank of the plateau.

Regardless of the mechanism for the increased supply to the deeper sites, the effects, we think, are dampened at the deeper sites because of carbonate dissolution and the position of the lysocline (Fig. 20). Lyle et al. (this volume) argue that other factors besides carbonate dissolution are responsible for sediment accumulation rates. Their results are much higher resolution than ours and are complicated, therefore, by other sedimentation processes. From Figure 20, if we assume that sediment accumulation relative to the top of the plateau is entirely a function of carbonate dissolution, we can attempt to track the position of the lysocline through time. The trends in our data at the crude resolution of the seismic stratigraphy are consistent from site to site (Fig. 20). Thus, we think that a shallow lysocline in the early Miocene caused sediment thinning, especially evident at Site 803, but apparent even at water depths as shallow as Site $806(2500 \mathrm{~m})$. A deepening of the lysocline occurred in the late early Miocene, causing relative thickening at each site. Within the 


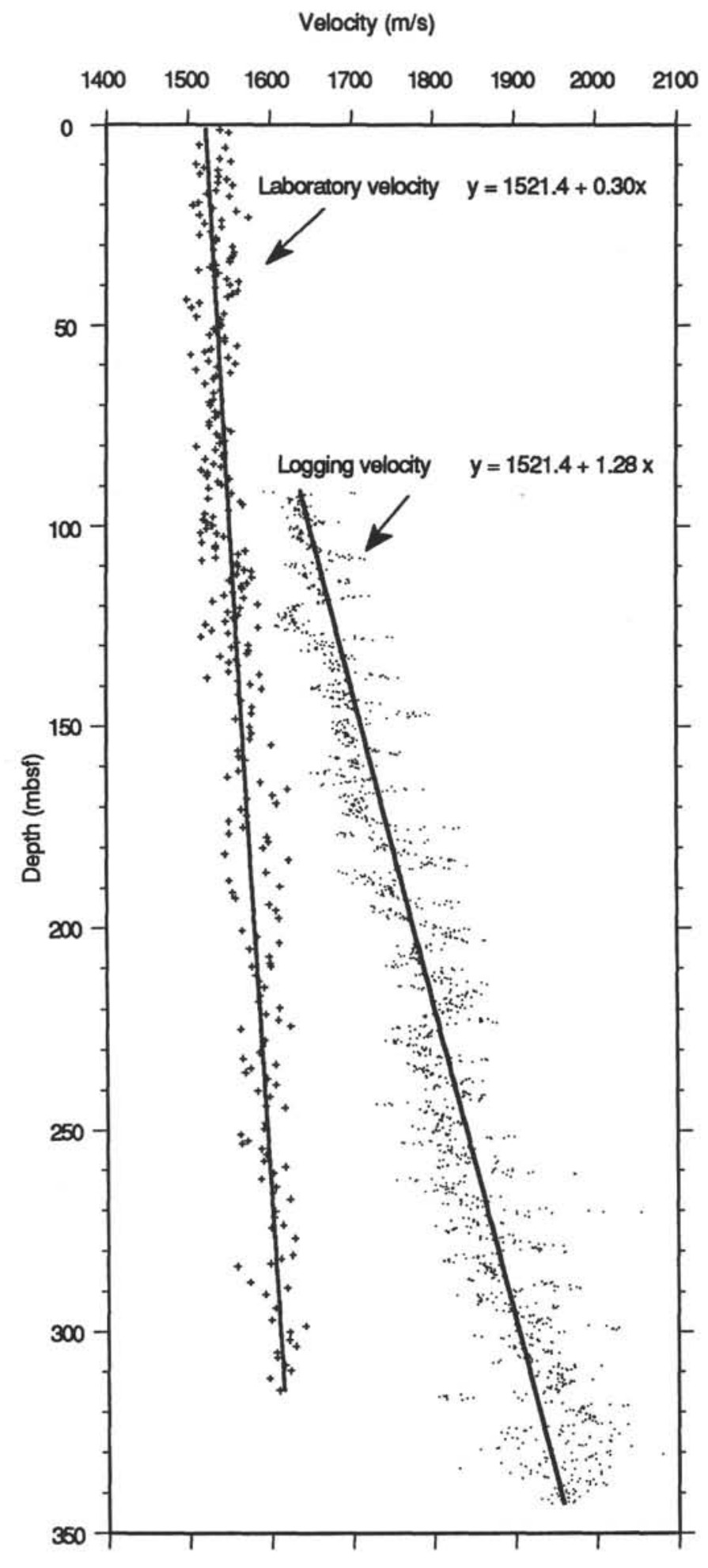

Figure 15. Plot of logging $P$-wave velocity and laboratory $P$-wave velocity (corrected for in-situ temperature, pressure, and density) vs. depth for the ooze interval at Site 806. The solid lines are the linear best-fit curves through the data. The linear fit through the logging data is forced through the same Y-intercept as the lab data, as velocity at the seafloor should be equivalent. The lab-velocity data is corrected to the trend of the logging velocity data to simulate assumed in-situ conditions. middle Miocene, between the R3 and R4 horizons, a sharp rise possibly took place in lysoclinal depth as well as a steepening of the dissolution gradient, resulting in sediment thinning at all four sites, though only slightly apparent at Site 806 . The effects of this increased dissolution can be seen in sediments of this age at Site 805, with a decrease in abundance of whole foraminifer as compared with sites on top of the plateau (Kroenke, Berger, Janecek, et al., 1991). Enhanced dissolution can reduce the relative importance of foraminifers in sediments because foraminifer preservation is more sensitive than calcareous nannofossil preservation to the position of the calcite lysocline (Berger and Johnson, 1976; Berger et al., 1977; Berger and Mayer, 1978). The thicker sections between the R2 and R3 horizons (late Miocene) likely correspond to a deepening of the lysocline. A subsequent rise in the lysocline again hinders accumulation of sediment in the very late Miocene and Pliocene. This rise results in some thinning of the section between the seafloor and the R2 horizon at Site 805 relative to Site 586 .

Figure 21 is an interpretation synthesis of the data presented in Figure 20, estimating lysoclinal depths from the amount of seismicstratigraphic thinning that has occurred at each site, assuming again that thinning is entirely related to carbonate dissolution. The trends do not fit particularly well with the CCD curve presented for the central equatorial Pacific (van Andel et al., 1975) (Fig. 21), although Farrell and Prell (1989) show that changes in the depth of the lysocline do not necessarily correlate with CCD changes. Van Andel et al. (1975) show only slight changes in the CCD through the Neogene, with a rise in the CCD in the early Miocene, and a slight lowering again in the middle Miocene. We would predict a shallow lysocline based on the degree of thinning in the middle Miocene. Similarly, the deepening of the lysocline we would predict in the late Miocene is not apparent on the CCD profiles (Fig. 21). These profiles also show a static to decreasing trend in the depth of the CCD through the Pliocene, whereas we would predict a shoaling of the lysocline. These results imply that the lysocline fluctuations do not follow CCD fluctuations, similar to conclusions of Farrell and Prell (1989), or that sediment thinning is driven by mechanisms other than carbonate dissolution.

\section{SUMMARY AND CONCLUSIONS}

The flank of the Ontong Java Plateau is an ideal setting to study carbonate sedimentation through a depth transect of carbonate-neutral water to carbonate-corrosive water. A study of these sediments with seismic reflection profiles, in collaboration with sediment stratigraphic data acquired through drilling, provides a powerful way to study the sedimentary history of the region in both spatial and temporal terms. Over 3000 line-kilometers of single-channel seismic reflection data and data from seven ODP drill sites on top of, and along the flank of, the Ontong Java Plateau comprise the data base for this study.

Results from ODP drilling include downhole compressional velocity and sediment bulk-density measurements. Laboratory measurements of these parameters on cores recovered from drilling had to be corrected to in-situ conditions. Density was corrected with a porosity rebound curve generated by Marsters and Manghnani (this volume); the correction is small ( $2.7 \%$ porosity at $1000 \mathrm{mbsf})$. Correction of velocity to in-situ conditions of pressure, temperature, and density (porosity rebound) does not entirely compensate the values to in-situ levels based on well-log results. We think that rigidity, which is largely dependent upon the depth of burial and grain-size distribution, is a significant component of the velocity formula in the case for carbonate sediments of the Ontong Java Plateau. This elastic parameter is difficult to measure and account for in soft sediment, so the laboratory-measured velocity has been further corrected to levels of downhole logging sonic velocity values, which are assumed to represent in-situ conditions. The corrections to velocity are significant. 


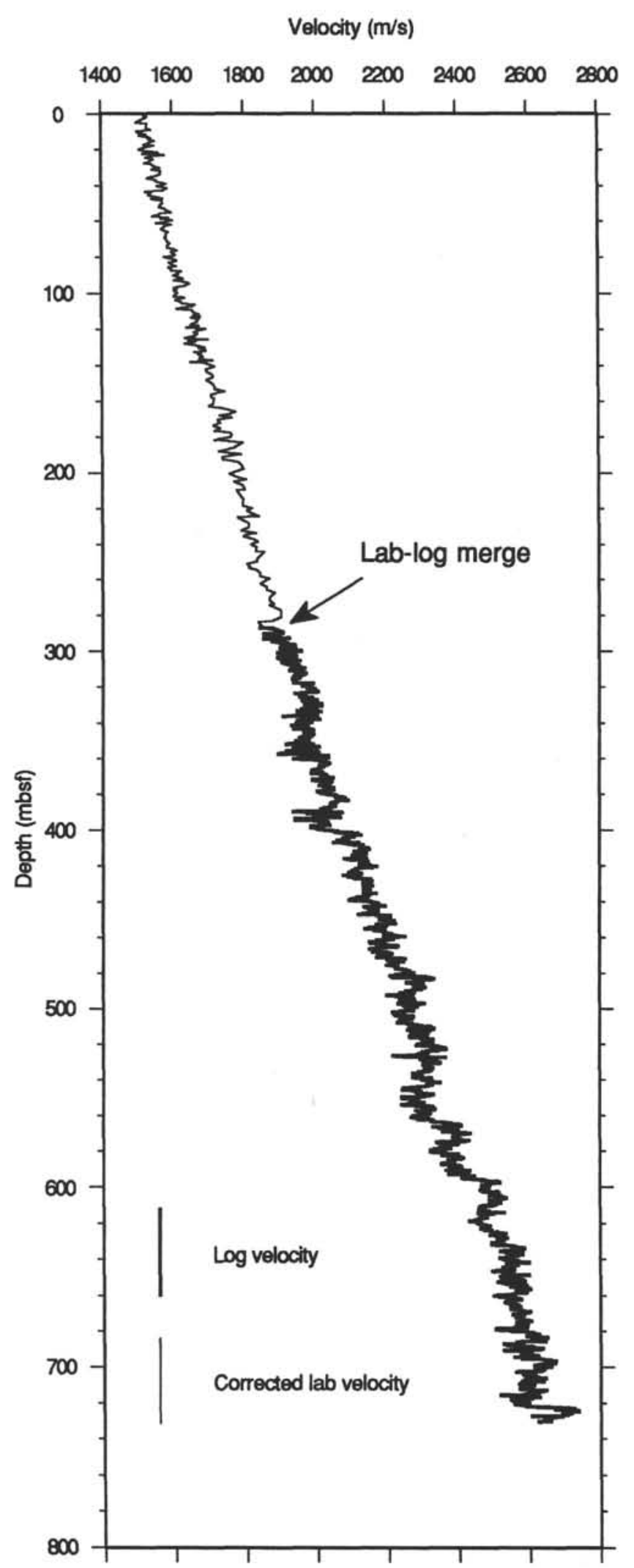

Figure 16. Plot of final corrected laboratory $P$-wave velocity and logging $P$-wave velocity vs. depth at Site 806 , showing that lab values are now congruent with log values. The lab values are substituted for log data over the ooze interval,
A
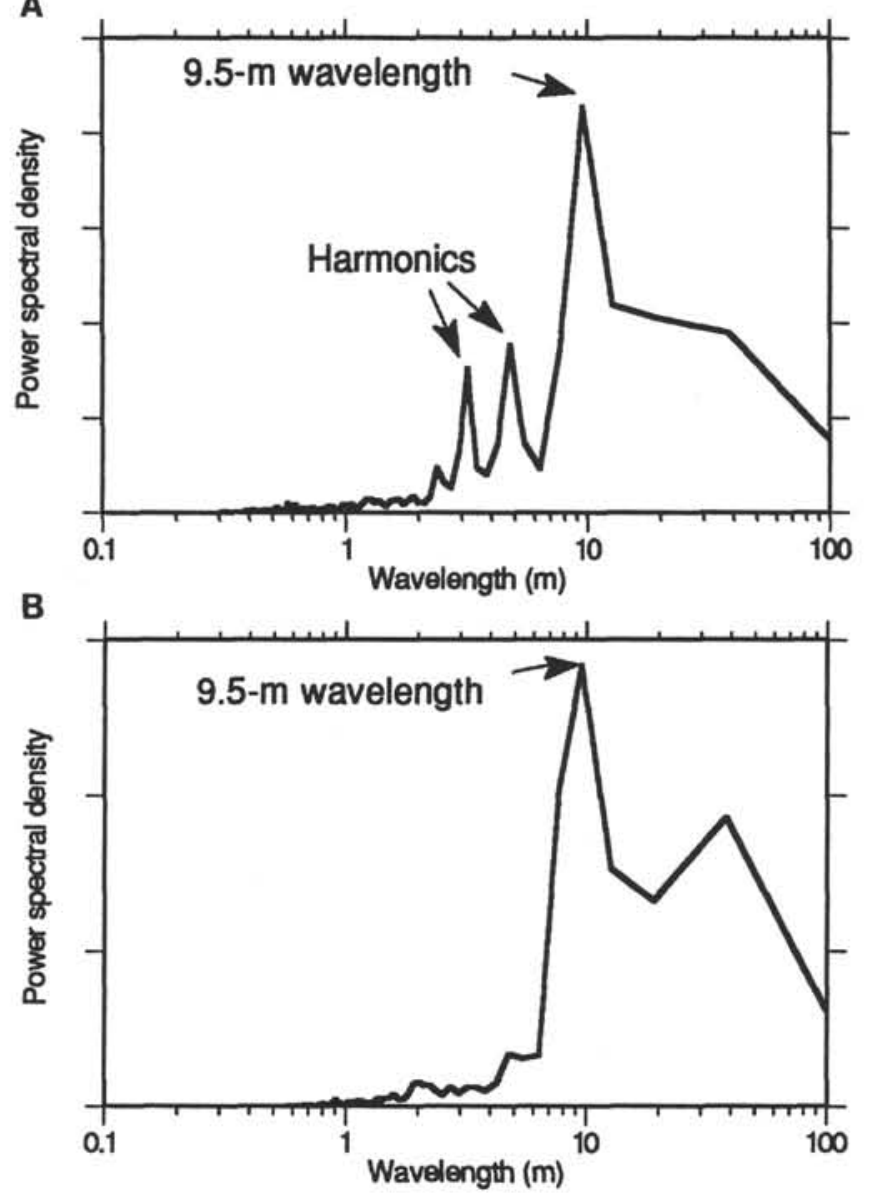

Figure 17. A. Power spectral density plot of logging velocity values for the ooze interval ( $80-350 \mathrm{mbsf}$ ) for Site 806 . The plot shows dominant power at a wavelength of $9.5 \mathrm{~m}$ and its harmonics $(4.75$ and $3.17 \mathrm{~m})$. This plot is used as an example to demonstrate that most of the variation in logging velocity data through the ooze interval is probably a result of coring disturbance (widening of the borehole during the coring process), because the advanced hydraulic piston core (APC) is precisely $9.5 \mathrm{~m}$ in length. This effect can be seen in the logging velocity data in the ooze intervals at each of the Leg 130 drill sites. B. A power spectral density plot of logging gamma-ray density values at Site 806, which also demonstrates the $9.5-\mathrm{m}$ wavelength power resulting from coring disturbance. In this case, however, the harmonic wavelengths are not present, either because they are probably dampened by real data or because the log density values are partly corrected for borehole diameter.

With velocity and density data available, it is possible to generate synthetic seismograms to assist in the correlation of core data to the seismic data. Correlation of the synthetic seismograms to the field seismic records suggests that the true in-situ velocities are $30 \mathrm{~m} / \mathrm{s}$ lower than those measured by sonic logging velocity analysis. These correlations permit the conversion of seismic traveltimes to depths below seafloor at each site (Table 1). Plotting this data, it was found that a single velocity-depth function exists for all sites on the Ontong Java Plateau, allowing a single equation to represent the transfer of traveltime to depth or vice versa, anywhere on the plateau (Fig. 18). This fact implies that depth of burial is the primary control on sediment compressional wave velocity, rather than age, or state of induration, which can vary from site to site. This finding agrees with the methods used in the correction of velocity to in-situ conditions, where velocity was corrected as a function of depth below seafloor, rather than as a function of any of the physical properties. It also supports the implication that the elastic moduli (primarily rigidity) 


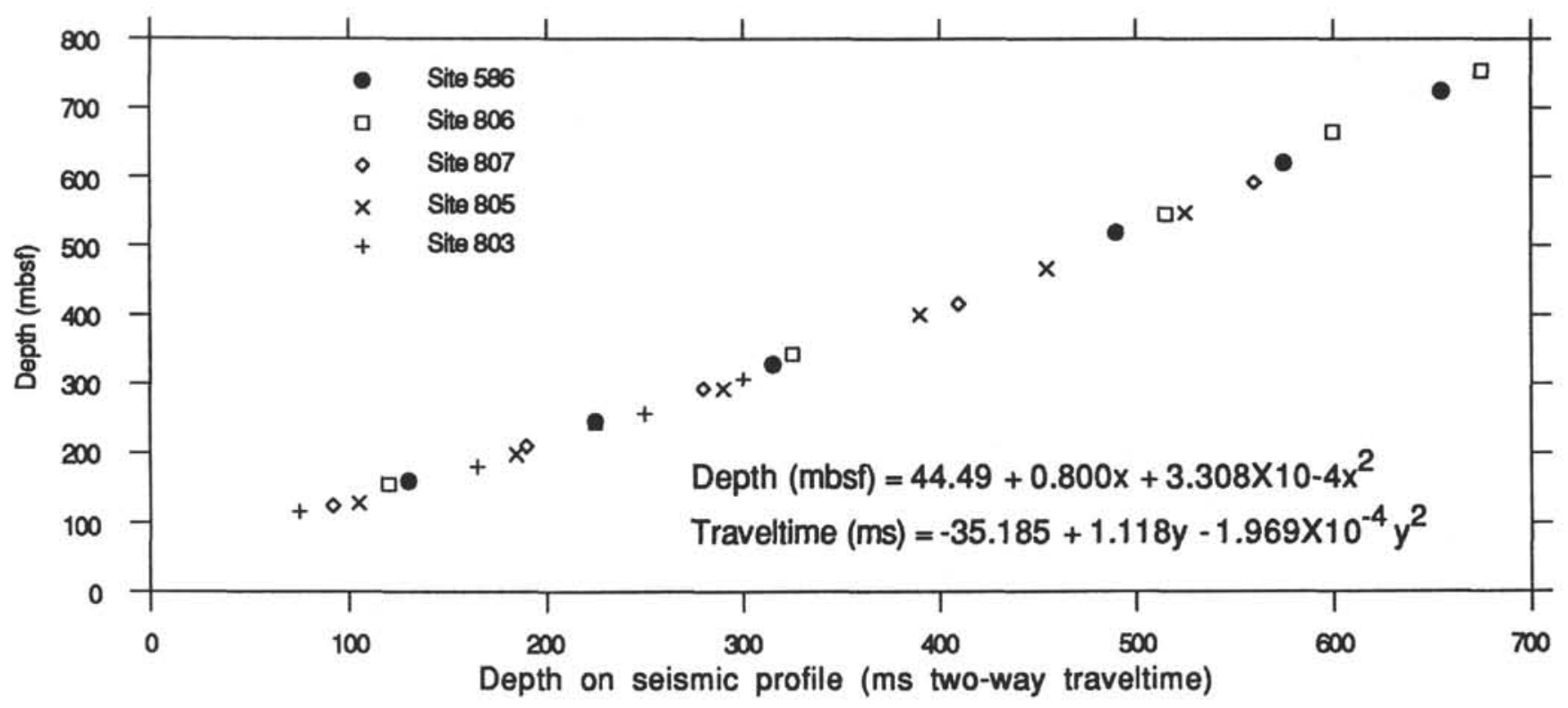

Figure 18. Cross plot of seismic stratigraphy and synthetic seismogram correlation results for each of the drill sites. Depth in meters is the ordinate axis, and traveltime below seafloor in milliseconds is the abscissa. Note that results from each of the sites plot on a single curve, suggesting that the velocity-depth function is nearly equivalent at each site. A second-order polynomial fit provides for converting traveltime on the seismic section (measured below the first high-amplitude seafloor return, not on the precursor) to depth in meters below seafloor throughout the study area. The equation of the fit is given, as is the inverse equation for converting depth to traveltime.

are the primary physical controls on the velocity of Ontong Java Plateau sediment. Because the sediments are of one type (carbonate), little lithologic control is exerted on velocity; and, under pressure from depth of burial, it seems that the sediments behave similarly, regardless of state of induration.

Seismic reflection profiles from the Ontong Java Plateau show three distinct changes in character with increasing water depth: (1) excessive thinning of the sediment column, (2) changes in the echocharacter (seismic facies), and (3) loss of continuous, coherent reflections. From the top of the Ontong Java Plateau down to about $2900 \mathrm{~m}$ water depth, the sediment column is about $1 \mathrm{~s}$ thick and is characterized by numerous, parallel, continuous, coherent, low-amplitude reflections in seismic profile. Correlation with drilling results indicates that these sediments were deposited by pelagic processes. The sediment is composed of about $90 \%$ biogenic carbonate material.

Between 2900 and $3375 \mathrm{~m}$ water depth, seismic profiles become more complex, with a variety of reflection patterns. Faulting, reflector pinchout and truncation, and totally incoherent reflections characterize this section of the flank. The sediment column thins significantly $(25 \%)$ through this interval. Seismic and core evidence indicate that these sediments are composed of pelagic carbonate; however, in places they are moderately to heavily modified by mass-movement processes.

Between 3375 and $3800 \mathrm{~m}$ water depth, seismic reflectors become more coherent and of higher amplitude, but faulting and resedimentation are still apparent on seismic profiles. Core evidence indicates that sedimentation was dominated by pelagic deposition, but sediment reworking and dissolution have occurred. High-amplitude reflections and variability in the seismic profiles support these findings.

Below $3800 \mathrm{~m}$, acoustic basement is characterized by a rough topography, possibly related to basement faulting, creating a series of horsts and grabens (Hagen et al., this volume). Sediments tend to infill the grabens. The sediment column yields reflections of different characteristics, lending to development of several seismic facies. Coring in one of these basins yielded a stratigraphy with a number of hiatuses, debris flows, and disturbed sediments. These interpretations support inferences made from the seismic records. It seems that much of the sedimentary record is missing or condensed. Physical property contrasts, as a result, are high, leading to high-amplitude reflections in the seismic profile.

The flank of the Ontong Java Plateau levels off in the Nauru Basin at about $4500 \mathrm{~m}$ water depth. Acoustic basement is smoother at this point. The sediment column is about $25 \%$ as thick as on top of the plateau. No sampling has been conducted at this depth, but seismic sections provide evidence of turbidite deposition and seafloor erosion.

Seismic stratigraphic analysis has shown that the sediment section decreases in thickness by $65 \%$ from $2200 \mathrm{~m}$ water depth on top of the plateau to $4000 \mathrm{~m}$ water depth near the base of the plateau. Thinning is attributed to increasing carbonate dissolution with depth, which is a function of the lysocline position and the CCD. If this assumption is true, then changes in the relative thicknesses of seismostratigraphic units at each drill site are indicative of changes in the position of the lysocline and the dissolution gradient between the lysocline and the CCD. We think it possible that a shallow lysocline in the early Miocene caused sediment thinning. Deepening of the lysocline in the late-early Miocene caused relative thickening at each site. Within the middle Miocene, a sharp rise occurs in the lysoclinal depth, concurrent with a possible steepening of the dissolution gradient, which resulted in sediment thinning at all four sites. The thicker sections in the late Miocene likely correspond to a deepening of the lysocline, and a subsequent rise in the lysocline again hinders accumulation of sediment in the very late Miocene and Pliocene.

\section{ACKNOWLEDGMENTS}

The authors would like to expressly thank the officers, crew, and scientific staff of JOIDES Resolution during Leg 130 and of Thomas Washington during Roundabout Leg 11. We would also like to thank Stephan Saustrup, Brian Nichols, and Peter Bugden for technical support. The Canadian Secretariat for the Ocean Drilling Program supplied travel funding for D. Mosher. D. Mosher was supported with a NSERC postgraduate scholarship and Dalhousie University fellowship. Support for this work was supplied in part by the Office of Naval Research Contract No. n00014-91-1213 and seismic data collection 
Table 1. Depths to reflectors on the field seismic data at each of the site crossings, correlations with synthetics at each site, and age assignments.

\begin{tabular}{|c|c|c|c|c|c|}
\hline \multirow[b]{2}{*}{ Site } & \multirow[b]{2}{*}{ Reflector } & \multicolumn{2}{|c|}{ Traveltime (ms) } & \multirow{2}{*}{$\begin{array}{l}\text { Depth } \\
\text { (mbsf) }\end{array}$} & \multirow{2}{*}{$\begin{array}{l}\text { Age } \\
\text { (Ma) }\end{array}$} \\
\hline & & Seismic & Synthetic & & \\
\hline \multirow[t]{6}{*}{803} & R1 & & & & \\
\hline & R2 & 75 & 148 & 116 & 6.8 \\
\hline & $\mathrm{R} 3$ & 165 & 225 & 181 & 9.2 \\
\hline & R4 & 250 & 310 & 257 & 17.3 \\
\hline & R5 & 300 & 360 & 307 & 24.5 \\
\hline & R6 & 315 & 380 & 327 & 25.7 \\
\hline \multirow[t]{6}{*}{805} & RI & 105 & 165 & 128 & 5.05 \\
\hline & R2 & 185 & 250 & 198 & 7.18 \\
\hline & R3 & 260 & 328 & 266 & 9.1 \\
\hline & R4 & 388 & 439 & 378 & 16.3 \\
\hline & R5 & 455 & 520 & 467 & 23.7 \\
\hline & R6 & 525 & 590 & 548 & 26.4 \\
\hline \multirow[t]{6}{*}{806} & R1 & 120 & 195 & 156 & 4.8 \\
\hline & $\mathrm{R} 2$ & 225 & 295 & 244 & 6.8 \\
\hline & R3 & 325 & 400 & 343 & 9.1 \\
\hline & R4 & 515 & 592 & 546 & 16.3 \\
\hline & R5 & 600 & 690 & 665 & 22.6 \\
\hline & R6 & 675 & 765 & 754 & 25.2 \\
\hline \multirow[t]{6}{*}{807} & R1 & 92 & 154.5 & 125 & 5.0 \\
\hline & R2 & 190 & 250.9 & 210 & 6.9 \\
\hline & R3 & 280 & 338.6 & 293 & 9.5 \\
\hline & R4 & 410 & 460 & 416 & 16.1 \\
\hline & RS & 490 & 554 & 521 & 22.2 \\
\hline & R6 & 560 & 616.6 & 592 & 24.5 \\
\hline \multirow[t]{6}{*}{$289 / 586$} & R1 & 130 & 195 & 160 & 5.0 \\
\hline & R2 & 225 & 290 & 246 & 7.2 \\
\hline & R3 & 315 & 375 & 328 & 9.7 \\
\hline & R4 & 490 & 555 & 519 & 17.0 \\
\hline & R5 & 575 & 640 & 620 & 22.7 \\
\hline & R6 & 655 & 725 & 713 & \\
\hline
\end{tabular}

Note: Age assignments come from Leg 130 biostratigraphic data (Kroenke, Berger, Janecek, et al., 1991).

was funded by a NSF-ODP grant to E.L. Winterer. The digital sound velocimeter (DSV) for shipboard velocity measurements was provided by the Département de Géologie Dynamique, Université Pierre et Marie Curie, and funded to Y. Lancelot by INSU/CNRS, France.

\section{REFERENCES*}

Berger, W.H., 1967. Foraminiferal ooze: solution at depths. Science, 156:383-385 1968. Planktonic foraminifera: selective solution and paleoclimatic interpretation. Deep-Sea Res., Pt. A, 15:31-45.

1970. Planktonic Foraminifera: selective solution and the lysocline. Mar. Geol., 8:111-138.

1989. Appendix: global maps of ocean productivity. In Berger, W.H., Smetacek, V.S., and Wefer, G. (Eds.), Productivity of the Ocean: Present and Past: New York (Wiley), 429-455.

Berger, W.H., Fischer, K., Lai, C., and Wu, G., 1988. Ocean carbon flux: global maps of primary production and export production. In Agegian, C.R. (Ed.), Biogeochemical Cycling and Fluxes Between the Deep Euphotic Zone and Other Oceanic Realms. NOAANational Res. Prog., Res. Rep. 88-1:131-176.

Berger, W.H., and Johnson, T.C., 1976. Deep sea carbonates: dissolution and mass wasting on Ontong-Java Plateau. Science, 192:785-787.

Berger, W.H., Johnson, T.C., and Hamilton, E.L., 1977. Sedimentation on Ontong-Java Plateau: observations on a classic "carbonate monitor." In Anderson, N.R., and Malahoff, A. (Eds.), The Fate of Fossil Fuel $\mathrm{CO}_{2}$ in the Oceans: New York (Plenum), 543-567.

* Abbreviations for names of organizations and publication titles in ODP reference lists follow the style given in Chemical Abstracts Service Source Index (published by American Chemical Society).
Berger, W.H., and Mayer, L.A., 1978. Deep-sea carbonates: acoustic reflectors and lysocline fluctuations. Geology, 6:11-15.

Boyce, R.E., 1973a. Physical Properties-methods. In Edgar, N.T., Saunders, J.B., et al., Init. Repts. DSDP, 15: Washington (U.S. Govt. Printing Office), 1115-1128.

, 1973b. Summary of physical properties. In Edgar, N.T., Saunders, J.B., et al., Init. Repts. DSDP, 15: Washington (U.S. Govt. Printing Office), $1067-1068$.

_ 1976. Sound velocity-density parameters of sediment and rock from DSDP drill Sites $315-318$ on the Line Islands Chain, Manihiki Plateau, and Tuamotu Ridge in the Pacific Ocean. In Schlanger, S.O., Jackson, E.D., et al., Init. Repts. DSDP, 33: Washington (U.S. Govt. Printing Office), 695-728.

Carlson, R.L., Christensen, N.I., and Moore, R.P., 1980. Anomalous crustal structures in ocean basins: continental fragments and oceanic plateaus. Earth Planet. Sci. Lett., 51:71-180.

Courtney, R., and Mayer, L.A., in press. Acoustic properties of fine-grained sediments from Emerald Basin: towards an inversion of physical properties using Biot's law. J. Acoustic. Soc. Am.

Das, D.M., 1983. Advanced Soil Mechanics: Washington (Hemisphere Publ.).

Farrell, J.W., and Prell, W.L., 1989. Climatic change and $\mathrm{CaCO}_{3}$ preservation: an 800,000 year bathymetric reconstruction from the central equatorial Pacific Ocean. Paleoceanography, 4:447-466.

Fulthorpe, C.S., Schlanger, S.O., and Jarrard, R.D., 1989. In-situ acoustic properties of pelagic carbonate sediments on the Ontong Java Plateau. $J$. Geophys: Res., 94:4025-4032.

Furumoto, A.S., Webb, J.P., Odegard, M.E., and Hussong, D.M., 1976. Seismic studies on the Ontong Java Plateau, 1970. Tectonophysics, 34:71-90.

Hamilton, E.L., 1970. Reflection coefficients and bottom losses at normal incidence computed from Pacific sediment properties. Geophysics, 35:995.

, 1971a. Elastic properties of marine sediments. J. Geophys. Res., 76:579-604.

1971b. Prediction of in-situ acoustic and elastic properties of marine sediments. Geophysics, 36:266-284.

, 1972. Compressional wave attenuation in marine sediments. Geophysics, 37:620-646.

, 1974. Geoacoustic models of the sea floor. In Hampton, L. (Ed.), The Physics of Sound in Marine Sediments: New York (Plenum), 181-221.

1980. Geoacoustic modelling of the sea floor. J. Acoust. Soc. Am., 68:1313-1340.

Hamilton, E.L., Bachman, R.T., Berger, W.H., Johnson, T.C., and Mayer, L.A., 1982. Acoustic and related properties of calcareous deep-sea sediments. $J$. Sediment. Petrol., 52:733-753.

Houtz, R.E., and Ludwig, W.J., 1979. Distribution of reverberant subbottom layers in the southwest Pacific basin. J. Geophys. Res., 84:3497-3304.

Hussong, D.M., Wipperman, L.K., and Kroenke, L.W., 1979. The crustal structure of the Ontong Java and Manihiki Oceanic Plateaus. J. Geophys. Res., 84:6003-6010.

Johnson, D.A., and Johnson, T.C., 1970. Sediment redistribution by bottom currents in the central Pacific. Deep-Sea Res., Pt. A, 17:157-169.

Kroenke, L.W., 1972. Geology of the Ontong-Java Plateau [Ph.D. dissert.]. Univ. of Hawaii, Honolulu.

Kroenke, L.W., Berger, W.H, Janecek, T.R., et al., 1991. Proc. ODP, Init. Repts., 130: College Station, TX (Ocean Drilling Program).

Kroenke, L.W., Resig, J.M., and Cooper, P.A., 1986. Tectonics of the southeastern Solomon Islands: formation of the Malaita Anticlinorium. In Vedder, J.G., Pound, K.S., and Boundy, S.Q. (Eds.), Geology and Offshore Resources of Pacific Island Arcs, Central and Western Solomon Islands. Circum-Pac. Counc. Energy Mineral Resour., Earth Sci. Ser, 4:109-116.

Langseth, M.G., Nalone, I., and Berger, D., 1971. Seafloor geothermal measurements from Vema Cruise 24. Columbia Univ. Tech. Rept., 3-CU-3-71.

Laughton, A.S., 1957. Sound propagation in compacted ocean sediments. Geophysics, 22:233-260.

Mayer, L.A., Courtney, R.C., and Moran, K., 1987. Ultrasonic measurement of marine sediment properties. Proc. Oceanogr., 87:1-139.

Mayer, L.A., Shipley, T.H., Theyer, F., Wilkens, R.H., and Winterer, E.L., 1985. Seismic modeling and paleoceanography at Deep Sea Drilling Project Site 574. In Mayer, L., Theyer, F., Thomas, E., et al., Init. Repts. DSDP, 85: Washington (U.S. Govt. Printing Office), 947-970.

Mayer, L.A.,Shipley, T.H., and Winterer,E.L., 1986. Equatorial seismic reflectors as indicators of global oceanographic events. Science, 233:761-764.

Mayer, L.A., Shipley, T.H., Winterer, E.L., Mosher, D.C., and Hagen, R.A., 1991. Sea Beam and seismic reflection surveys on the Ontong Java Plateau. 
In Kroenke, L.W., Berger, W.H., Janecek, T.R., et al., Proc. ODP, Init. Repts., 130: College Station, TX (Ocean Drilling Program), 45-75.

Moore, T.C., and Heath, G.R., 1967. Abyssal Hills in the central equatorial Pacific: detailed structure of the seafloor and subbottom reflectors. Mar. Geol., 5:161-179.

Mudie, J.D., Grow, J.A., and Bessey, J.S., 1972. A near-bottom survey of lineated abyssal hills in the equatorial Pacific. Mar. Geophys. Res., 1:397-411.

Resig, J.M., Buyannanonth, V., and Roy, K.J., 1976. Foraminiferal stratigraphy and depositional history in the area of the Ontong-Java Plateau. Deep-Sea Res., Pt. A, 23:441-456.

Shipboard Scientific Party, 1971. Site 64. In Winterer, E.L., Riedel, W.R., et al., Init. Repts. DSDP, 7, Pt. 1: Washington (U.S. Govt. Printing Office), 473-606.

, 1975. Site 289. In Andrews, J.E., Packham, G., et al., Init. Repts. DSDP, 30: Washington (U.S. Govt. Printing Office), 231-398.

Shipboard Scientific Parties of Legs 89 and 90, 1986. Site 586: western equatorial Pacific. In Kennett, J.P., von der Borch, C.C., et al., Init. Repts. DSDP, 90: Washington (U.S. Govt. Printing Office), 19-114.

Shipley, T.H., Mayer, L.A., and Winterer, E.L., 1989. Seismic reflections and sedimentation in the pelagic equatorial Pacific. In Bally, A.W. (Ed.), Atlas of Seismic Stratigraphy. AAPG, 3:224-231.

Shipley, T.H., Winterer, E.L., Goud, M., Hills, S.J., Metzler, C.V., Paull, C.K., and Shay, J.T., 1985. Sea Beam bathymetric and water-gun seismic reflection

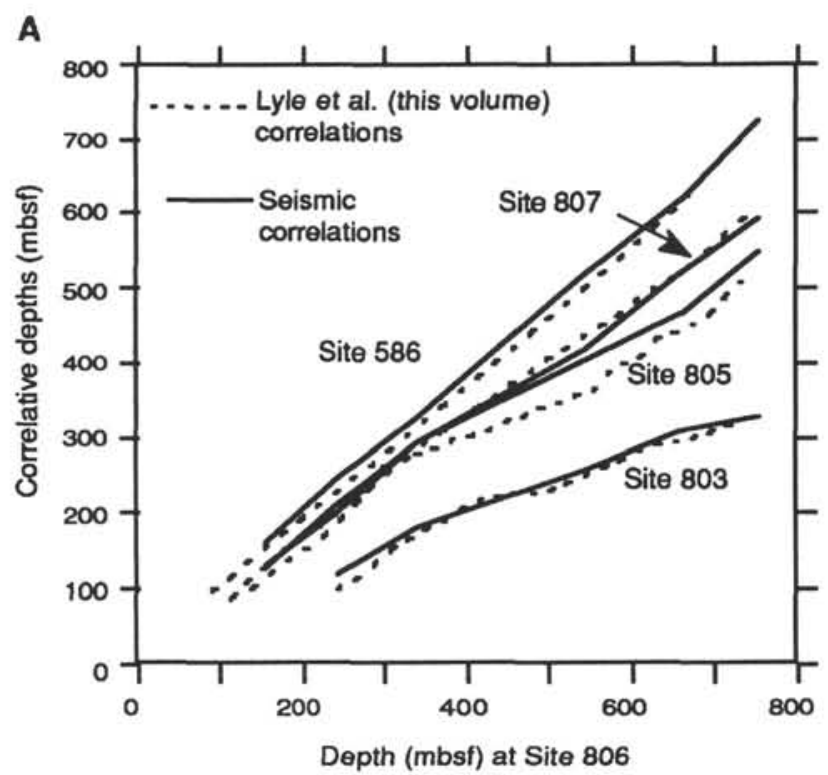

surveys in the equatorial Pacific. In Mayer, L., Theyer, F., Thomas, E., et al., Init. Repts. DSDP, 85: Washington (U.S. Govt. Printing Office), 825-837.

van Andel, T.H., Heath, G.R., and Moore, T.C., Jr., 1975. Cenozoic History and Paleoceanography of the Central Equatorial Pacific Ocean. Mem. Geol. Soc. Am., 143.

Wilson, W.D., 1960. Speed of sound in sea water as a function of temperature, pressure and salinity. J. Acoustic. Soc. Am., 32:641-644.

Wood, A.B., 1941. A Textbook of Sound: New York (MacMillan Press).

Wu, G., and Berger, W.H., 1991. Pleistocene ${ }^{18}$ Orecords from the Ontong-Java Plateau: effects of winnowing and dissolution. Mar. Geol., 96:193-209.

Wu, G., Yasuda, M.K., and Berger, W.H., 1991. Late Pleistocene carbonate stratigraphy on Ontong Java Plateau in the western equatorial Pacific. Mar. Geol., 99:135-150.

Wyllie, M.R.J., Gregory, H.R., and Gardner, L.W., 1956. Elastic waves in heterogeneous and porous media. Geophysics, 22:41.

Date of initial receipt: 2 December 1991

Date of acceptance: 10 August 1992

Ms 130B-047

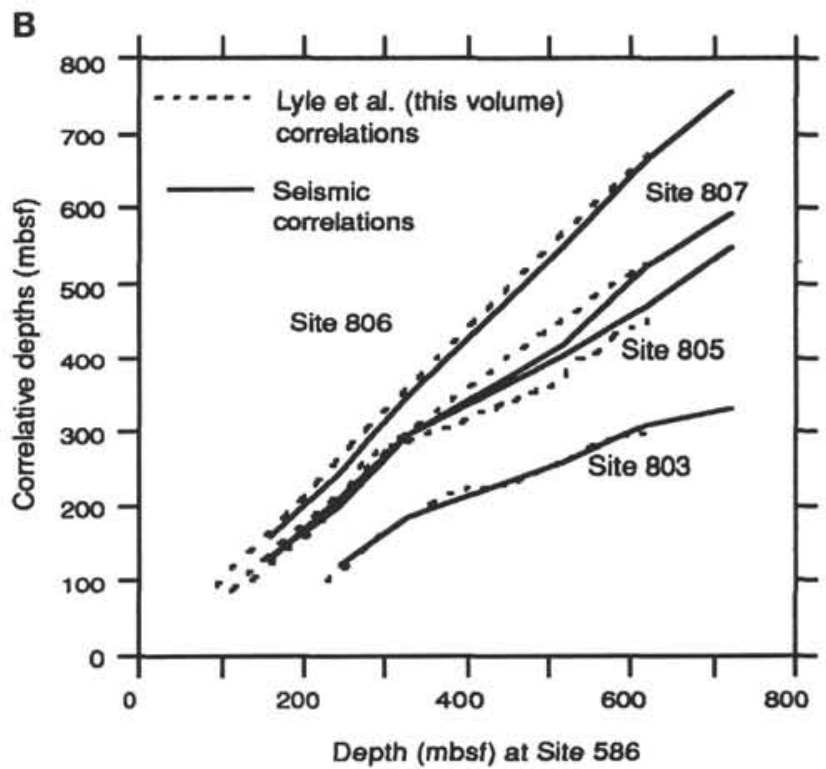

Figure 19. A. Comparison plot of correlative depths at Site 806 vs. other sites, using seismic stratigraphy correlations (traveltimes converted to depths below seafloor using synthetic correlations), and Lyle et al. (this volume) correlations using an inverse signal correlation technique, comparing sites based on the shape of logging density and resistivity curves. B. Equivalent to Figure 19A, but depths at Site 586 are used as abscissa values. The correlations of Lyle et al. (this volume) are given in greater detail (about $1-\mathrm{m}$ spacing) than the seismic correlations, which are based on a maximum of six horizons, spaced throughout the sediment column. 


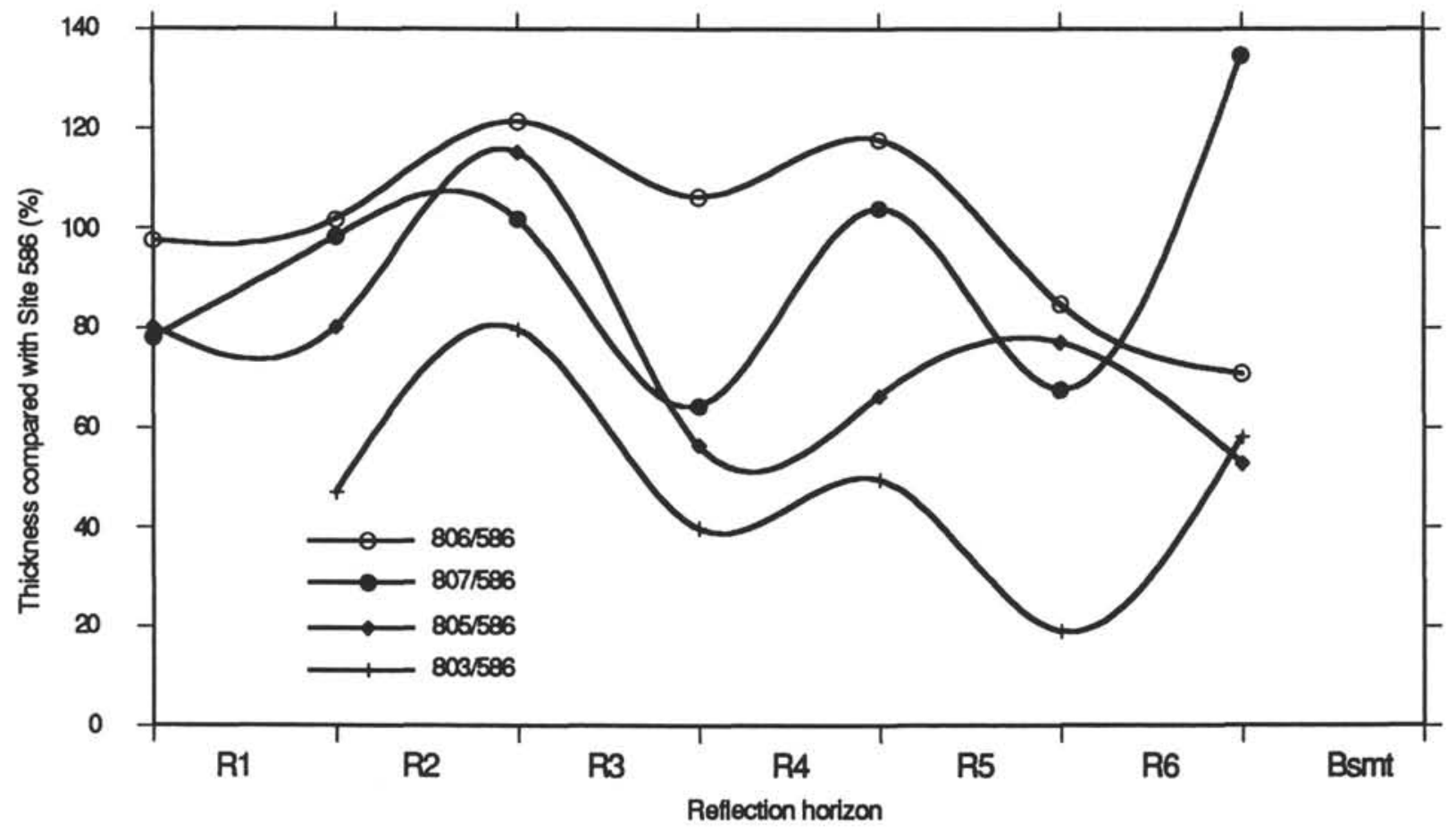

Figure 20. Plot of percent thickness of seismostratigraphic units (i.e., seafloor to R1, R1 to R2, R2 to R3, R3 to R4, R4 to R5, R5 to R6, and R6 to acoustic basement [Bsmt]) at each drill site compared with thicknesses at Site 586. If a value is $>100 \%$, it is thicker than at Site 586 ; if $<100 \%$, it is thinner. Thickness measurements were derived from depth in meters below seafloor, which in turn were derived from the results of the synthetic-seismic correlations (see Table 1). The curves are cubic spline fits through the data points. We think these thickness measurements can be used to map out the relative positions of past lysoclines.

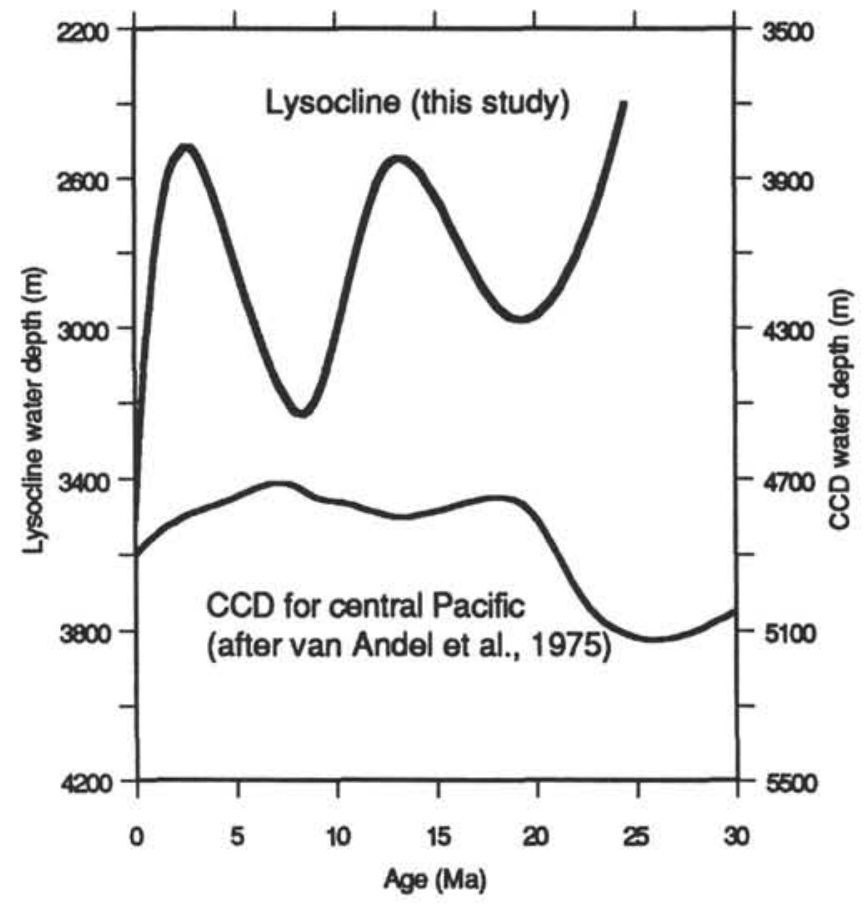

Figure 21. Approximate position of the lysocline through the Neogene as determined by the amount of relative thinning apparent from seismic stratigraphy data through the drill sites. To produce this curve, we have assumed that sediment thinning is caused entirely by carbonate dissolution, and that water depths of the drill sites are about the same through the Neogene as at present. The CCD depths, as reported by van Andel et al. (1975) for the central equatorial Pacific, are plotted with this curve. The two curves bear little resemblance to one another.
Table 2. Summary of ages assigned to seismic reflectors in Table 1.

\begin{tabular}{ccl}
\hline Reflector & $\begin{array}{c}\text { Age } \\
(\mathrm{Ma})\end{array}$ & \multicolumn{1}{c}{ Epoch } \\
\hline R1 & $4.8-5.05$ & Pliocene/Miocene boundary \\
R2 & $6.8-7.2$ & \\
R3 & $9.1-9.7$ & late/middle Miocene boundary \\
R4 & $16.1-17.3$ & middle/early Miocene boundary \\
R5 & $22.2-24.5$ & \\
R6 & $24.5-26.4$ & Miocene/Oligocene boundary \\
\hline
\end{tabular}

